\title{
Crop immunity against viruses: outcomes and future challenges
}

\author{
Valérie Nicaise* \\ Fruit Biology and Pathology, Virology Laboratory, Institut National de la Recherche Agronomique, University of Bordeaux, UMR 1332, Villenave d'Ornon, France
}

\section{Edited by:}

Benjamin Schwessinger, University of California, Davis, USA

\section{Reviewed by:}

Helene Sanfacon, Pacific Agri-Food Research Centre - Agriculture and Agri-Food Canada, Canada Jean-François Laliberté, Institut National de la Recherche Scientifique, Canada

\section{*Correspondence:}

Valérie Nicaise, Fruit Biology and

Pathology, Virology Laboratory, Institut National de la Recherche

Agronomique, University of Bordeaux, UMR 1332, 71 Avenue Edouard

Bourlaux, Bordeaux-Aquitaine,

CS 20032, 33882 Villenave d'Ornon,

France

e-mail:vnicaise@bordeaux.inra.fr
Viruses cause epidemics on all major cultures of agronomic importance, representing a serious threat to global food security. As strict intracellular pathogens, they cannot be controlled chemically and prophylactic measures consist mainly in the destruction of infected plants and excessive pesticide applications to limit the population of vector organisms. A powerful alternative frequently employed in agriculture relies on the use of crop genetic resistances, approach that depends on mechanisms governing plant-virus interactions. Hence, knowledge related to the molecular bases of viral infections and crop resistances is key to face viral attacks in fields. Over the past 80 years, great advances have been made on our understanding of plant immunity against viruses. Although most of the known natural resistance genes have long been dominant $R$ genes (encoding NBS-LRR proteins), a vast number of crop recessive resistance genes were cloned in the last decade, emphasizing another evolutive strategy to block viruses. In addition, the discovery of RNA interference pathways highlighted a very efficient antiviral system targeting the infectious agent at the nucleic acid level. Insidiously, plant viruses evolve and often acquire the ability to overcome the resistances employed by breeders. The development of efficient and durable resistances able to withstand the extreme genetic plasticity of viruses therefore represents a major challenge for the coming years. This review aims at describing some of the most devastating diseases caused by viruses on crops and summarizes current knowledge about plant-virus interactions, focusing on resistance mechanisms that prevent or limit viral infection in plants. In addition, I will discuss the current outcomes of the actions employed to control viral diseases in fields and the future investigations that need to be undertaken to develop sustainable broad-spectrum crop resistances against viruses.

Keywords: plant virus, $\boldsymbol{R}$ gene, recessive resistance, gene silencing, systemic acquired resistance, PAMP-triggered immunity, crop improvement

\section{INTRODUCTION}

As obligatory intracellular parasites, plant viruses depend on the host machinery to multiply and invade their hosts. In their simplest form, viruses consist of a DNA or RNA genomic segment encoding only few genes and encapsided into a protein shell, called the capsid. Because of natural physical barriers (cuticle, cell wall), viruses are delivered into plant cells through wounds or through the action of vectors (insects, nematodes, fungi) that feed on or infect the plants. Following entry into a host cell and genome decapsidation, the infectious cycle includes translation and replication of the viral genome, assembly of progeny virus particles, generalized invasion of the host through cell-to-cell and long-distance movements of viral particles or ribonucleoprotein complexes and finally, transmission to new hosts by vectors. In some cases, transmission to the following generation of host plant is also observed as a result of seed infection. In 2012, the International Committee on Taxonomy of Viruses reported 92 genera of plant viruses of which 82 were assigned in 21 different families (King et al., 2012).

Plant infection by viruses causes physiological disorders responsible for plant diseases of economic and agronomic significance in many crops. Widely employed in fields, the use of plant varieties carrying genetic resistances constitutes the most effective, economical and ecological measure to control viral infections. The last decades have seen substantial advances on the molecular dialog between viral pathogens and their plant hosts, bringing new strategies directly exploitable in crop improvement programs. Nevertheless, the spread of crop viral pests has increased dramatically in recent years. Globalization, trade and climate change, as well as reduced resilience in production systems due to decades of agricultural intensification have all played a part.

This review intends: (i) to provide a brief overview of severe virus-associated plant diseases and their impact on crop production, (ii) to summarize prophylactic strategies employed to control viral epidemics in fields, (iii) to bring an update on current knowledge about plant resistances against viruses, (iv) to present the technical approaches currently employed in crop improvement programs, and (v) to discuss how antiviral mechanisms based on PAMP-triggered immunity (PTI) could be the source of novel plant resistances in fields.

\section{WHAT IS THE REAL IMPACT OF VIRAL DISEASES ON CROPS?}

Management of plant virus diseases is a matter of vital importance and concern to farmers, horticulturists, foresters, manufacturers, 
as well as consumers. It is well-established that virus diseases in different crops cause enormous losses all over the world in terms of quantity and/or quality of products. Although it's very difficult to put a clear figure on the financial impact of plant viruses in agriculture, the yield losses that can be ascribed to plant viruses are estimated to cost worldwide more than $\$ 30$ billion annually (Sastry and Zitter, 2014).

Amongst the most damaging virus-associated threats, strains of Cassava mosaic begomoviruses cause more than 25 million tons of losses per year in Africa, India, and Sri Lanka (Legg and Thresh, 2000; Calvert and Tresh, 2002; Thresh and Cooter, 2005). Because the Cassava crop represents the daily staple for more than 500 million people all over the world, epidemics are often associated to famine events (Legg, 1999; Legg and Thresh, 2000; Calvert and Tresh, 2002). Potato leafroll polerovirus is responsible for an annual potato loss of $\$ 100$ millions in the US and $\mathfrak{£} 30-50$ millions in UK (Wale et al., 2008; Sastry and Zitter, 2014). The losses in citrus tree cultures attributed to Citrus Tristeza closterovirus (CTV) were estimated to over 100 million trees worldwide (Moreno et al., 2008; Harper, 2013). Barley yellow dwarf is the most widely distributed viral disease of cereals, affecting oats, rice, barley, maize, and wheat. It is caused by Barley yellow dwarf luteovirus, that costs producers in $\mathrm{UK}$ alone about $\mathfrak{1} 10$ million a year in lost production (Ordon et al., 2009; Sastry and Zitter, 2014). It is estimated that the international costs of managing the Sharka disease [caused by Plum pox potyvirus (PPV)] since the 1970s have exceeded 10 billion euros (Cambra et al., 2006). Viruses affecting rice cultures result in yield losses estimated at more than $\$ 1.5$ billion in South-East Asia alone (Abo and Sy, 1998; Hull, 2013; Sasaya etal., 2013). Discovered in Ghana in the middle of the 20th century, Cacao swollen shoot badnavirus is currently endemic in Togo, Ghana, and Nigeria. Over 200 million trees have already been eradicated, representing the most costly effort of any country in the world against a viral plant disease (Dzahini-Obiatey et al., 2010).

It's important to mention that diseases of perennial and fruit crops not only lead to the loss of the crop but the loss of time and cost in bringing the trees to bearing, the losses of other crops that could have been grown on the land during that time, and the differences in the value of the land with and without a productive orchard. Moreover, virus-associated losses in fields are highly under-estimated as some viral infections are asymptomatic alone but contribute in a synergic manner to damages due to attacks from other pathogens (Hull, 2013). More importantly, viruses have been described causing half of the reported emerging infectious diseases from plants (Anderson et al., 2004). Hence, viruses represent serious crop threats, responsible for considerable agronomical losses, global food problem, and human life overall all over the world.

\section{PROPHYLACTIC MEASURES IN FIELDS}

Because viral agents are obligate intracellular parasites, curative treatments of virus infections are impossible, making viral diseases very difficult to control in fields. Prophylactic control measures are therefore crucial in combating epidemics on crops. They consist mainly on combining cultural practices, biosecurity measures and organism-vector management (Figure 1).

\section{PERFORM REGULAR INSPECTION FOR THE PRESENCE OF VIRAL PATHOGENS}

In this domain, the rising up of molecular biology techniques combined to continuous characterization of new etiological agents improved significantly the sensitivity, the specificity and the rapidity required to an accurate diagnosis of plant pathogenic viruses (Boonham et al., 2014). The reliability of the available diagnosis tests is a key point in viral disease management in fields, as infected plants need to be eradicated as fast as possible to minimize the virus spread.

\section{MONITOR ORGANISM-VECTOR POPULATIONS}

Plant viruses need to be transmitted by an organism-vector (insects, nematodes, zoosporic endoparasites) for their plant-toplant spread. Hence, viral diseases can be efficiently controlled by limiting the populations of their vectors with the applications of appropriate pesticides. The use of non-host "trap plants" may be also considered to attract vectors to reduce the number of individuals feeding on the crop of interest and thus, the transmission of the disease (Bragard et al., 2013).

\section{SET UP A RIGOROUS CONTROL PROGRAM ON WEEDS AND OTHER HOST PLANTS IN THE VICINITY OF THE FIELD}

Epidemics often arise from new viruses or new variants of classic viruses that spilled over from reservoir species to crops. Although this phenomenon results from a complex evolutionary process in which the main players are ecological factors, virus genetic plasticity and host factors, viral diseases can be controlled by managing the spatial structure and composition of field parcels, which impacts resistance durability (Elena et al., 2011; Fabre et al., 2012).

\section{RESPECT THE PHYTOSANITARY MEASURES DECREED BY VARIOUS INTERNATIONAL COMMISSIONS}

Minimizing viral epidemics involves the respect of international legislations concerning worldwide trade of virus-free plant material, which applies to any development stage of a plant that can be carrier of viruses (seeds or fruit stones, grafts, rootstocks, seedlings, flowers,...), as well as manipulation of decontaminated horticultural tools.

\section{USE CROP CULTIVARS THAT ARE RESISTANT TO VIRUSES}

The use of genetically resistant plants is one of the most efficient, sustainable and frequently employed strategies to control virus infections in fields. For centuries, it has involved plants selected by breeders for their agronomic proprieties combined to the absence of disease symptoms. However, from the middle of the 20th century, plant improvement programs capitalize strongly on the knowledge associated to plant-virus interactions to develop resistant varieties exploitable in agriculture.

\section{WHAT DO WE KNOW ABOUT PLANT IMMUNITY AGAINST VIRUSES?}

Faced with viral attacks, plants defend themselves through several resistance layers, that are complementary in terms of defense timing (at early or late infection steps), location (in the first infected leaf or in systemic tissues) and targeting the virus-derived molecules (the viral genome or the viral proteins; Figure 2). 


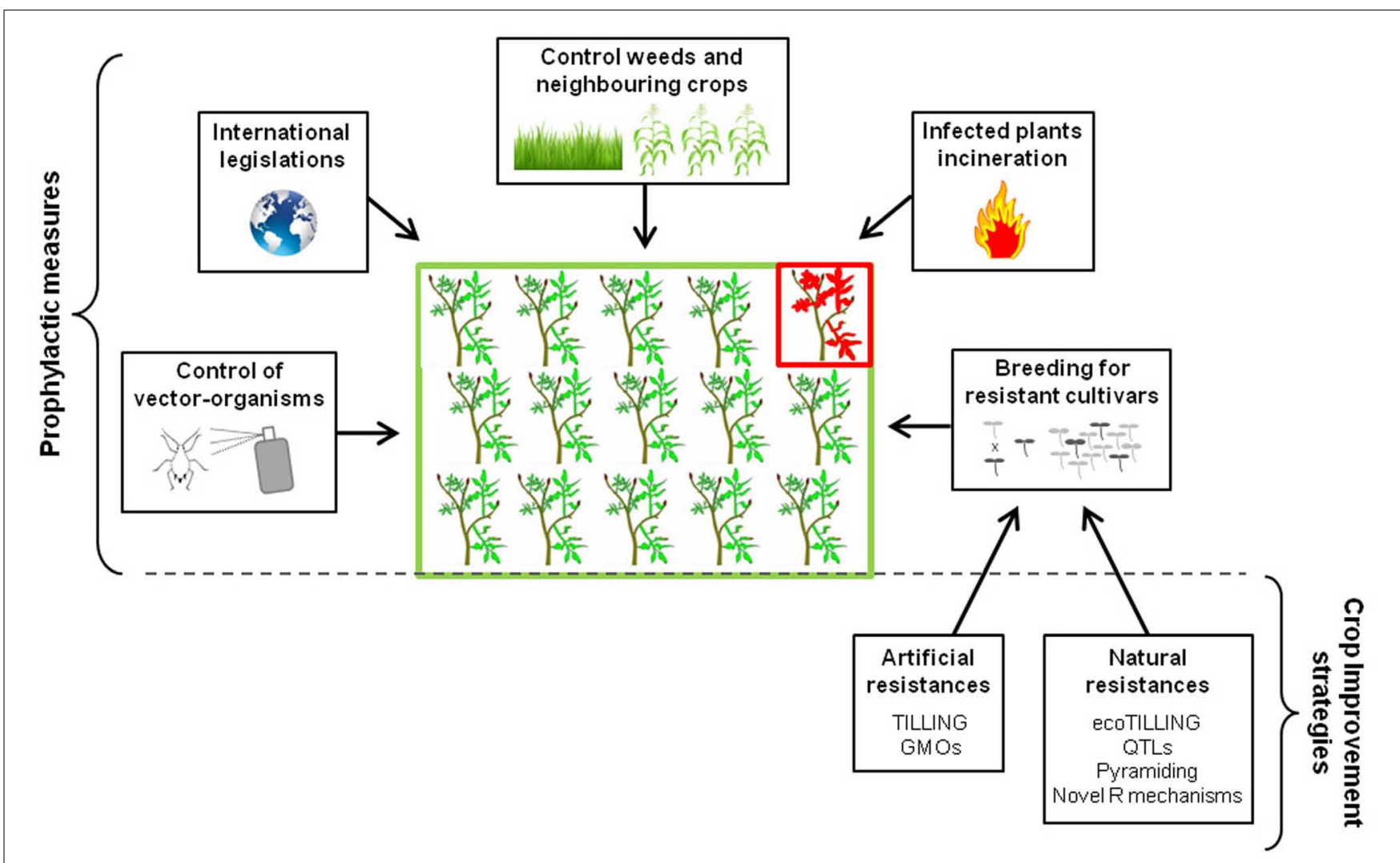

FIGURE 1 | Prophylactic measures and main crop improvement strategies employed to control plant viral diseases.

\section{DOMINANT RESISTANCES}

The majority of dominant resistance genes ( $R$ genes) identified in plant-virus interactions belong to the nucleotide binding siteleucine-rich repeat (NBS-LRR) class, that specifically recognize the viral avirulence (avr) gene products, through the establishment of the so-called "gene-for-gene" interaction. Although a direct physical interaction between the $a v r$ and $R$ gene products had originally been suggested, the current understanding favors the more sophisticated "guard hypothesis" model (Soosaar et al., 2005). Many NBS-LRR proteins conferring resistance against viruses have been identified so far, and are classified on the basis of their $\mathrm{N}$-terminal structure, that carries either a Toll-interleukin-1 receptor (TIR) domain or a coiled-coil (CC) domain (Moffett, 2009; De Ronde et al., 2014).

One of the best characterized example is the potato $R x 1$ gene that encodes a typical CC-NBS-LRR protein and mediates resistance to Potato potexvirus X (PVX) through the recognition of the PVX capsid (CP). Rx1 CC domain has been shown to form a heterodimer with the cellular ranGTPase-activating protein 2 (ranGAP2), interaction required for Rxl function (Rairdan et al., 2008; Tameling et al., 2010). Although direct interaction between ranGAP2 and PVX CP has not been detected, it has been proposed that ranGAP2 might nonetheless interact with the $\mathrm{CP}$, causing a conformational change perceived by the rest of the protein and leading Rx to switch to an active state (Hao et al., 2013). In another well-characterized $R$ gene example, the tobacco $N$ gene product, that displays a TIR-NBS-LRR structure, interacts directly with the helicase domain of the replicase of Tobacco mosaic tobamovirus (TMV), in an ATP dependent manner (Figure 2A; Ueda et al., 2006). Full resistance to TMV requires the N receptor-interacting protein 1 (NRIP1), which is recruited from the chloroplast to the cytoplasm and nucleus and interacts with both viral replicase and $\mathrm{N}$ factor (Caplan et al., 2008). In both $R x 1$ and $N$ cases, the $R$ gene product is activated in the cytoplasmic compartment, while its nucleocytoplasmic distribution is required for full functionality (Slootweg et al., 2010; Tameling et al., 2010). The study of $N$ - and $R x$-mediated resistances have led to characterize the $\mathrm{R}$ signaling cascade in plant-virus interactions, that include rapid activation of MAP kinases and the action of a molecular chaperone complex composed of SGT1 (Suppressor of G2 allele of SKP1), HSP90 (Heat shock protein), and RAR1 (Required for Mla resistance 1; Azevedo et al., 2006; Botër et al., 2007; Kobayashi et al., 2010; Hoser et al., 2013), whose role seems to both stabilize R factors and mediate their degradation, thereby maintaining a tight cellular balance between defense signaling and attenuation (Kadota and Shirasu, 2012).

Immune events downstream of $\mathrm{R}$ protein activation are frequently associated with calcium ion influx, MAPK-mediated signaling, reactive oxygen species (ROS) production, salicylic acid (SA) accumulation, and extensive transcriptional reprogramming. In addition, the activation of $R$ genes is most of the time associated with a hypersensitive response (HR), a phenomenon involving the 


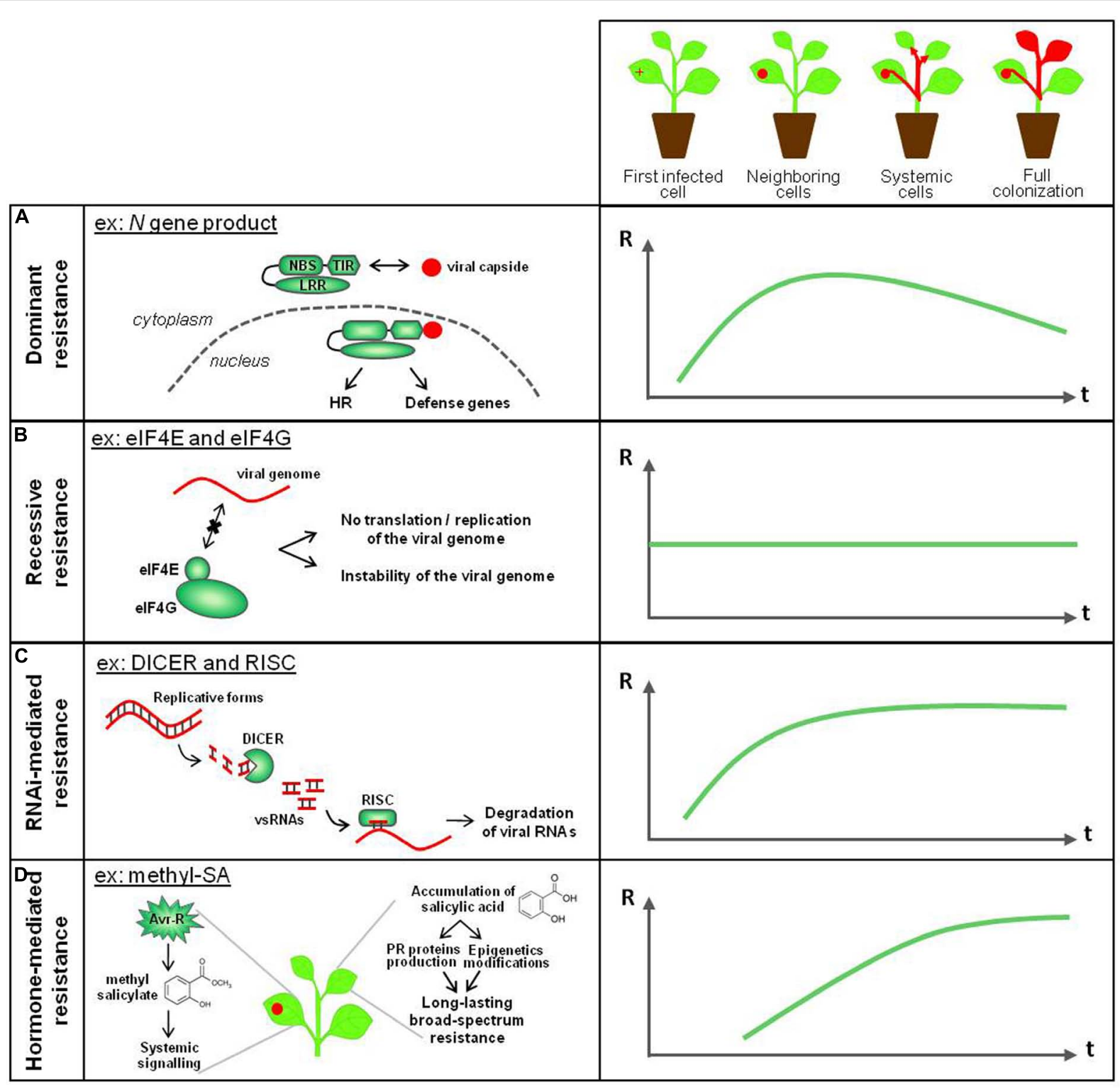

FIGURE 2 | Known antiviral immune mechanisms in plants. Plant resistance mechanisms against viruses are complementary in terms of plant defense timing, location (from the first infected cell to the generalized colonization) and targeting the virus-derived molecules (genome or proteins from viruses). (A) NBS-LRR dominant resistance relies on the interaction between an avirulence factor and a specific $R$ gene product, and is effective several days after the virus entry into the plant. The HR-associated phenomenon confines the viral pathogen in the infected and neighboring cells. (B) Recessive resistance, that corresponds to the absence of appropriate host factors that are required for the virus cycle, is a non-inducible resistance, passive and effective throughout plant colonization. It confers resistance at the infection step that requires the cellular factor of interest. (C) RNA interference (RNAi) targets viral nucleic acids. Once set up after few days, the effectiveness of this defense mechanism increases and spreads to the whole plant through a relay-amplification process. (D) Hormone-mediated resistance against viral pathogens is represented here by the role of salicylic acid (SA) and methyl-salicylate (Me-SA) in systemic acquired resistance (SAR). On graphs, R, resistance level; t, infection timing. programmed death of the infected and neighboring cells, with the consequences to confine the pathogen in the hypersensitive lesion and to prevent any further pathogen spread in the plant. A functional module that mediates HR against viruses (as well as non-viral pathogens) requires the interaction of two lipases, EDS1 (Enhanced disease susceptibility 1) and PAD4 (Phytoalexin deficient 4) with the protein SAG101 (Senescence-associated gene 101; Liu et al., 2002; Marathe et al., 2002; Wagner et al., 2013).
In Arabidopsis, the EDS1/PAD4/SAG101 complex regulates HRTmediated resistance against Turnip crinkle carmovirus (Zhu et al., 2011). Recent insights into $\mathrm{R}$ protein downstream signaling indicate that the resistance process and the HR-programmed cell death are distinct physiological pathways, although both can work in concert (Bendahmane et al., 1999; Bai et al., 2012). Meanwhile $R$ gene mediated defense is taking place locally, it also induces defense signaling in distally located tissues, called systemic acquired 
resistance (SAR), a mechanism that has been demonstrated for both $N$ and $R x 1$ genes (Delaney etal., 1994; Liu et al., 2010) and that is described in the Section "Plant Hormone-Mediated Resistance" of this review.

In contrast with the structure of the classical $R$ genes, the RTM genes (for Restricted TEV Movement) were the first cloned non-NBS-LRR dominant resistance genes against viruses. Genetic characterization of natural Arabidopsis accessions and mutants showed that at least five dominant RTM genes are involved in resistance to Tobacco etch potyvirus (TEV), Lettuce mosaic potyvirus (LMV), and PPV (Cosson et al., 2012). It has been recently proposed that RTM members may form a phloem-resident multiprotein complex involved in the resistance mechanisms to block the long-distance movement of potyviruses (Cosson et al., 2010a,b). No induction of HR or production of SA has been detected, in contrast with NBS-LRR mediated resistance responses (Mahajan et al., 1998). Another example of a non-NLS-LRR dominant resistance conferring resistance to TMV comes from the tomato Tm-1 gene, which encodes a protein with a TIM-barrel like structure, that interacts directly with the viral replicase, strongly impairing the viral genome replication (Ishibashi and Ishikawa, 2013).

\section{RESISTANCE RECESSIVES}

Around one-half of the approximately 200 known resistance genes that target plant viruses are recessively inherited (Diaz-Pendon et al., 2004), suggesting that this form of resistance is more common for viruses than for other plant pathogens. The use of such genes is therefore a very important tool in breeding programs to control plant diseases caused by pathogenic viruses.

Recessive resistances are often achieved through the absence of appropriate host factors that are required for the virus to complete its biological cycle. Over the last decade, a large number of recessive resistance genes have been cloned from crop species and shown to encode eukaryotic initiation factors (eIFs) belonging to the eIF4E and eIF4G families (Figure 2B; Truniger and Aranda, 2009; Wang and Krishnaswamy, 2012; Julio et al., 2014; Revers and Nicaise, 2014). These factors belong to the cellular $43 \mathrm{~S}$ complex, that recruit both mRNAs and ribosomes before the process of translation (Pestova et al., 2001) and are hypothesized to act as susceptibility factors recruited during the replication/translation steps of the viral genome. Firstly highlighted for successful potyvirus infection, the role of eIF4E and eIF4G have been quickly extended to other plant virus families, involving bymoviruses, cucumoviruses, ipomoviruses, sobemoviruses, carmoviruses, and waikiviruses (Revers and Nicaise, 2014), suggesting that they contribute to a broad mechanism of plant susceptibility to viruses. An intriguing aspect of eIF4E- and eIF4G-mediated resistances is that they cover a diverse range of resistance phenotypes. Although in many investigated cases they govern complete qualitative resistance, they have also been shown in some instances to provide partial resistance or to be components of partial or polygenic resistances (Caranta etal., 1997; Nicaise et al., 2003; Acosta-Leal and Xiong, 2008; Charron et al., 2008). Interestingly, ectopic overexpression of an $\mathrm{eIF} 4 \mathrm{E}$ resistance gene generates dominant potyvirus resistance in tomato and potato crops (Kang etal., 2007; Cavatorta etal., 2011), probably through the fact that the abundance of the "resistant eIF4E" makes the endogenous "susceptible eIF4E" inaccessible for its recruitment by viruses. Other components belonging to the translational machinery were demonstrated to be required for virus multiplication in Arabidopsis thaliana and Nicotiana benthamiana, including the translation initiation factor $4 \mathrm{~B}$ (eIF4B), the translation elongation factors $1 \mathrm{~A}$ and $1 \mathrm{~B}$ (eEF1A and eEF1B) and the poly(A)-binding proteins (PABPs) 2, 4, and 8 (Sasvari et al., 2011; Patarroyo et al., 2012; Hwang et al., 2013; Li et al., 2014b). These results suggest that crop genes encoding these translation factors may lead to new resistance sources that need to be explored for viral disease control.

Other susceptible recessive resistance genes which are not encoding translation initiation factors have been identified through the analysis of mutants collections and/or natural cultivated or wild species. A positional cloning strategy exploring barley natural variability revealed recently the key role of the PDI5-1 (Protein disulfide isomerase like 5-1) protein in the recessive resistance to bymoviruses (Yang et al., 2014). Another recessive resistance gene named $r a$ blocking vascular transport of Potato potyvirus A (PVA) was genetically characterized in potato (Hämäläinen et al., 2000). In addition, from the perspective of identifying new resistance sources, exploring Arabidopsis genetic diversity has provided original insights into the genes involved in plant-virus interactions, which could be used as potentially resistance sources against viruses. For example, the recessive resistance genes $r \operatorname{lm} 1$ and $r p v 1$, conferring resistance to LMV and PPV respectively, map in a genomic region containing no translation factor genes (Revers et al., 2003; Decroocq et al., 2006). The lack of co-segregation with eIF4E or eIF4G genes is also true for dstm1 mediating TMV resistance (Serrano et al., 2008) and sha3, a major quantitative trait locus (QTL) contributing to systemic resistance against PPV (Pagny et al., 2012). Very recently, data revealed that the gene $r w m 1$ conferring resistance to Watermelon mosaic potyvirus in Arabidopsis acts at an early stage of infection by impairing viral accumulation in initially infected leaf tissues and encodes a conserved nucleus-encoded chloroplast phosphoglycerate kinase (Ouibrahim et al., 2014). In the case of tom 1 and tom $2 A$ Arabidopsis mutants, TMV accumulation is suppressed in single cells. After further characterization, it appears that both genes encode transmembrane proteins localized in the tonoplast and are required for tobamovirus replication (Ishibashi et al., 2012). Consistent with the fact that viral replication complexes associate with host intracellular membranes (Hull, 2013), prospective studies identified many membraneassociated components as key factors required for plant infection success, providing new candidates for novel genetic sources of crop resistances (Diaz et al., 2010; Hyodo et al., 2013; Barajas et al., 2014a,b).

\section{RNA INTERFERENCE MEDIATED-RESISTANCE}

Over the past decades, RNA interference (RNAi; also called gene silencing) has been recognized as an evolutionarily conserved process in most eukaryotes, that is triggered by double-stranded RNAs (dsRNAs). These dsRNAs are processed by ribonuclease III-type DICER-like (DCL) enzymes into small RNAs (sRNAs), 21-24 nucleotides in length, that are incorporated into an RNA-induced cytoplasmic silencing complex (RISC), whose key 
catalytic component corresponds to one member of the ARGONAUTE (AGO) protein family. Once integrated into the RISC, sRNAs base-pair to their target-mRNA and induce their cleavage (Bologna and Voinnet, 2014). In plants, silencing pathways are particularly diverse and partially overlapping. At least, three basic processes can be distinguished: cytoplasmic RNA silencing (or post-transcriptional gene silencing; PTGS) mediated by small interfering RNAs (siRNAs), silencing-mediated by plant-encoded microRNAs (miRNAs) and transcriptional gene silencing (TGS) mediated by siRNA-directed methylation of DNA and histone proteins. Key components of these RNA silencing pathways have been shown to have an important protective role against invading viral pathogens (Bologna and Voinnet, 2014).

Most plant viruses have RNA genome that commonly contain double-stranded secondary structure elements and/or produce dsRNA intermediates via the action of viral RNA-dependent RNA polymerases (RDRs) during the replication step. These molecules are targeted by the RNA-silencing machinery to produce virus-derived small RNAs (vsRNAs; Pumplin and Voinnet, 2013; Figure 2C). What initially appeared counter-intuitive, infection from DNA viruses produce also dsRNAs, most likely via bidirectional convergent transcription (Aregger et al., 2012). The integration of vsRNAs in the RISC leads to the sequence-specific degradation of viral nucleic acids, as well as the generation of a mobile-silencing signal, which spreads between cells through plasmodesmata and over long-distances via the phloem, through a relay-amplification process involving host RDRs (Pumplin and Voinnet, 2013). This process activates RNA silencing in noninfected cells and is notably responsible for the plant recovery phenomenon. Given gene silencing induces immune mechanisms highly specific to the pathogen, it is commonly accepted that RNAi is classified into plant adaptive immunity (Voinnet, 2001; Waterhouse et al., 2001).

Encoded by multigene families, plant DCLs, RDRs and AGOs are often specialized in the production and function of the distinct sRNA classes. Despite its universality, current knowledge remains incompletely understood, as it relies mostly on reverse genetic studies conducted in Arabidopsis. This notwithstanding, it appears clear that specific RNAi-associated components are involved in silencing antiviral functions. Thus, DCL4 is the major enzyme for generating RNA virus-derived vsRNAs, even if DCL2 can substitute for DCL4 to some extent (Blevins et al., 2006; Deleris et al., 2006; Qu et al., 2008; Jakubiec et al., 2012). In contrast, all four DCLs (DCL1-4) produce DNA virus-derived vsRNAs (Akbergenov et al., 2006; Moissiard and Voinnet, 2006; Blevins et al., 2011). So far, only AGO1, AGO2, and AGO7 seem to contribute to antiviral RNAi (Morel et al., 2002; Qu et al., 2008; Shivaprasad et al., 2008; Azevedo et al., 2010; Harvey et al., 2011; Jaubert et al., 2011; Wang et al., 2011; Zhang et al., 2012). In particular, RNA viruses-derived vsRNAs seem to be strongly recruited by AGO1 and AGO2 proteins, an observation consistent with the hyper-susceptibility of ago1 ago2 double mutants (Wang etal., 2011). Antiviral RNAi has also been shown to be dependent on one or more of RDR1, RDR2, and RDR6 for signal initiation and/or amplification (Diaz-Pendon et al., 2007; Qu et al., 2008; Qi et al., 2009; Vaistij and Jones, 2009; Garcia-Ruiz et al., 2010; Wang et al., 2011; Jiang et al., 2012). An increase of susceptibility against RNA viruses is also observed in Arabidopsis plants defected for the gene HEN1 (for HUA ENHANCER 1) encoding a methyltransferase that protects siRNA and miRNA duplexes from degradation (Vogler et al., 2007; Zhang et al., 2012). Interestingly, the natural resistance genes $T y-1$ and $T y$ - 3 conferring resistance to Tomato yellow leaf curl begomovirus (TYLCV) has been recently shown to encode a tomato RDR. Although resistant plants do not show symptoms upon a challenge with TYLCV, low levels of virus are still detectable, a phenomenon characteristic of a virus tolerance more than a real resistance (Verlaan et al., 2013).

Viruses have evolved diverse mechanisms to avoid silencingmediated resistance, most notably through silencing suppressor activities. Identified for almost all types of plant viruses, silencing suppressors target RNAi pathways at different points and through diverse mechanisms, including the impair of siRNA biogenesis, the defect of siRNA incorporation into the RISC, the degradation of AGOs, the trapping of sRNAs and the suppression of RNAi amplification (reviewed in Burgyán and Havelda, 2011; Pumplin and Voinnet, 2013; Bologna and Voinnet, 2014; Li et al., 2014a). In turn, increasing evidence suggest that plants have evolved by establishing specific defenses against RNA-silencing suppression by pathogens, providing yet another illustration of the never-ending molecular arms race between plant pathogens and their hosts (Pumplin and Voinnet, 2013; Sansregret et al., 2013).

\section{PLANT HORMONE-MEDIATED RESISTANCE}

Plant hormones play important roles in regulating signaling networks involved in plant defenses. Upon pathogen attack, the quantity, composition and timing of the plant hormonal blend produced by the plant depends greatly on the lifestyle and infection strategy of the invading attacker. In the last decades, significant progress has been made in identifying the key components and understanding the role of phytohormones in plant responses to biotic stresses (Robert-Seilaniantz et al., 2011).

During the R-mediated resistance activation (see the Section "Dominant Resistances" in this review), cellular responses elicited at the infection site are emitted to distant non-infected tissues, resulting in a resistance or in reduced susceptibility state that can remain efficient during several weeks (Fu and Dong, 2013). This phenomenon is referred as the SAR (Figure 2D). In the case of TMV-triggered HR, the response persists up to 3 weeks during the time plants are protected against not only TMV but also other pathogens (Ross, 1961). How SAR can be sustained for so long is not clear but epigenetic modifications, such as DNA methylation and chromatin remodeling, seem critical to maintain a SAR signal (Spoel and Dong, 2012). Moreover, during a viral infection (in a manner similar to non-viral infections), this long lasting and broad-spectrum disease resistance requires endogenous accumulation of SA, resulting in transcriptional reprogramming of a battery of genes encoding pathogenesis-related (PR) proteins (Tsuda et al., 2008; Yi etal., 2014). The signal emitted by the infection spot to protect the uninfected tissues against pathogen invasion may circulate as an heterocomplex, where methyl-SA binds to lipid derivatives and lipid-transport proteins and moves through the phloem to the rest of the plant. Thus, studies on 
TMV-infected tobacco plants revealed that MeSA participates to the perpetuation of SAR defense (Park etal., 2007; Dempsey and Klessig, 2012). Recent data suggest that the composition of the mobile immune signal in SAR relies on a complex network of cross-interacting signals (e.g., MeSA, glycerol-3-phosphate, the lipid-transfer protein DIR1 and the amino acid-derivative pipecolic acid), that differs depending on the plant species and the type of plant-pathogen interaction (Vlot et al., 2008; Dempsey and Klessig, 2012; Spoel and Dong, 2012). Jasmonic acid (JA) is also strongly involved in plant defense against viruses and the $\mathrm{HR}$ response initiated by Avr-R protein interactions results on a modulation of SA and JA. Although SA clearly acts as a positive regulator of plant resistance to viruses, the role of JA is controversial and remains to be fully elucidated. For example, JA seems to regulate negatively the local resistance to TMV in tobacco (Oka et al., 2013) but is essential for systemic resistance to TMV in $N$. benthamiana (Zhu et al., 2014). It is likely that a balance between endogenous JA and SA play a key role for determining the degree of resistance, in a similar way to pathosystems involving non-viral plant pathogens (Thaler et al., 2012). Interestingly, plant viruses have evolved targeting hormone pathways, often exploiting the antagonistic interactions between SA and JA pathways (Kazan and Lyons, 2014). Although their function in plant-virus interactions remains poorly understood, recent studies indicate that other plant hormones modulate antiviral resistance mechanisms, especially abscisic acid (Chen et al., 2013; Alazem et al., 2014; Seo et al., 2014), ethylene (Fischer and Dröge-Laser, 2004; Love et al., 2007; Zhang et al., 2009; Chen et al., 2013), and brassinosteroids (Ali et al., 2014).

\section{CROP IMPROVEMENT AND VIRAL PEST MANAGEMENT: MODERN TECHNOLOGY TO THE RESCUE}

Ultimately, the main objective of research on plant-virus interactions consists on the implementation of efficient antiviral resistances in crop plants. For long, genetics-mediated resistance strategies have involved exploiting plant natural variability by introgression of resistance genes through a classical breeding process. However, the onset of evolved pathogens able to overcome these resistance, sometimes very rapidly after resistance deployment (García-Arenal and McDonald, 2003), raised the problem of crop resistance durability and thus the urge to develop new breeding strategies. The last decades saw the emergence of new approaches combining modern technology and state-of-the-art knowledge on plant-virus interactions toward crop improvement programs, triggering a new green revolution in agriculture.

\section{TECHNICAL ASSETS FROM MARKER-ASSISTED SELECTION}

The conventional breeding represents a laborious and time consuming process. In this context, the advent of DNA marker techniques such as random amplified polymorphic DNA (RAPD), restriction fragment length polymorphism (RFLP), amplified fragment length polymorphism (AFLP), and simple sequence repeats (SSRs) contributed, through what is called "Marker-assisted selection (MAS)," to make substantially easier, quicker, and more accurate the selection of resistant genotypes during the introgression steps (Collard and Mackill, 2008). Importantly, this progress has recently been driven by next generation sequencing(NGS-) based technologies successfully employed for de novo whole genome shotgun (WGS) sequencing of reference genotypes and whole genome resequencing (WGRS) of several cultivars, land races, and wild relatives (Mascher and Stein, 2014). Despite the fact that the creation of improved varieties via the MAS strategy is still at its infancy (Collard and Mackill, 2008), MAS has an enormous potential and represents a great challenge of molecular breeding in the 21 st century.

\section{EXPLOITING RESISTANCE-ASSOCIATED OTLS}

It is probable that only a small proportion of the natural biodiversity available for disease resistance has been exploited so far. Although more than $80 \%$ of reported plant resistances to viruses are monogenically controlled, most agronomic traits in crop plants do not segregate as single defined qualitative monogenic characters but as quantitative and polygenically controlled traits (Maule et al., 2007). Mapping QTL for quantitative resistance requires large sized progenies, nearly saturated genetic maps, as well as reliable and quantitative phenotyping procedures. To date, relatively few QTLs analyses have been performed in plant-virus interactions compared to other pathogens (Maule et al., 2007; Palloix and Ordon, 2011). It is a general assumption that the greater the number of mutations required for virus virulence, the more durable is the resistance. Consequently, the higher durability of polygenic resistances in plant-virus interactions is commonly hypothesized and has recently been validated in the case of pepper resistance to Potato potyvirus Y (Palloix et al., 2009; Quenouille et al., 2013). Notwithstanding their clear relevance, QTLs present particular technical challenges for their characterization as well as their incorporation into crops, leading them to be mostly dropped in favor of approaches using monogenic resistances or combining several known major genes.

\section{GENE PYRAMIDING STRATEGY}

The concept of transferring several characterized resistance genes into one plant is called "Gene Pyramiding." The dogma behind this strategy is that the probability of a pathogen mutating to "virulence against all resistance genes in the pyramid would be the product of the probabilities for each gene singly" (Mundt, 2014), thus making the probability of a virulent pathotype arising highly unlikely. Hence, pyramiding relies on resistance genes that have been previously characterized singly and whose functions are combined within the same plant. This strategy has been successfully applied to plant-virus interactions (Werner et al., 2005; Palloix et al., 2009; Shi et al., 2009) and could bring the opportunity to associate different types of antiviral plant resistances targeting different virus-derived molecules (proteins or nucleic acids) and various processes during virus cycle (replication/translation, plasmodesmata crossing, systemic colonization), with the possible consequence to reduce significantly the probability of resistance breaking by new virus variants (Quenouille et al., 2013). Despite arduous population sizes required for multiple resistance genes along with other agronomical traits, gene pyramiding is gaining considerable importance in plant-pathogen interactions and thus is representing an ambitious challenge for crop improvement programs. 


\section{ENGINEERING RESISTANCES}

Genetic engineering directly manipulates the genome of a plant by inducing the expression of novel proteins or by modulating the expression of targeted genes. The genetically modified (GM) plants resistant to viral attacks are grouped into three major categories. First of all, resistance genes with a dominant determinism can be introduced to another plant species. The best examples in plant-virus interactions involve the successful transfer of $R$ genes into solanaceous related plants (Whitham et al., 1996; Bendahmane et al., 1999; Baurès et al., 2008; Candresse et al., 2010) but it seems also possible across plant families (Seo et al., 2006). The opportunity to introduce $R$ genes from sexually incompatible species is, however, weakened by the fact that most $R$ genes display a limited-spectrum resistance. Alternative transgenic approaches have also been developed based on the integration of a viral protein or genomic region into the host plant, through a phenomenon called pathogen-derived resistance (PDR). Initially reported in transgenic tobacco plants expressing the TMV CP (Abel et al., 1986), the resistance observed was ultimately ascribed to the action of the transgene-encoded CP, which disturbs the disassembly of incoming TMV particles. In many other studies, resistance was obtained through the expression of partial or non-coding viral sequences. This kind of resistance, more efficient that the proteinmediated resistance, was later shown to be based on the RNAi mechanism (Tenllado et al., 2004). These observations led to a plethora of RNAi-mediated engineered resistances, using virusderived double-stranded, hairpin RNAs, or artificial miRNAs (e.g., Qu et al., 2007; Hashmi etal., 2011; Shimizu et al., 2011; Yadav et al., 2011; Zhang et al., 2011a,b; Lin et al., 2012; Shekhawat et al., 2012; Lemgo etal., 2013; Odipio etal., 2013; Zhao and Song, 2014). In the cases where virus-resistant GM varieties have been deployed and/or commercialized (including transgenic squash, papaya, plum, potato, and bean), this strategy has so far proven to be remarkably efficient (Tricoli et al., 1995; Lius et al., 1997; Ferreira et al., 2002; Malinowski etal., 2006; Zagrai et al., 2008; Bravo-Almonacid et al., 2012; Aragão et al., 2013). In spite of engineering resistance success (especially RNAi-based resistant crops), public concerns over the potential ecological impact of GM crops and GM organisms overall have so far significantly limited their use, in particular in Europe.

\section{THE TILLING AND ECOTILLING REVOLUTION}

The early 2000s have seen the emergence of the TILLING (Targeting Induced Local Lesions IN Genomes) method, that consists of a classical mutagenesis step followed by the targeted search for plants carrying a mutation in a gene of interest (McCallum et al., 2000). By creating artificial polymorphism directly into crops, this technique allows potentially: (i) to replace a resistance allele overcome by viral strains, (ii) to generate novel resistances with a broader spectrum, or (iii) to create a new resistance gene based on knowledge acquired in heterologous systems. Such a strategy increase the natural allelic diversity by the identification of novel artificial alleles. Although this strategy requires the previous characterization of the gene conferring the resistance, the main advantage of TILLING is that it can be applied to any plant species, regardless of its genome size, ploidy level or method of propagation, and without introducing heterologous DNA as for GM plants. Similarly, the
TILLING natural alternative (using natural germplasms collections instead of EMS mutants collections) is calling ecoTILLING and consists of exploiting the whole natural variability of a plant species (including wild-related and cultivated genotypes; Comai et al., 2004). Initially developed in A. thaliana, both TILLING and ecoTILLING have spread rapidly to other model plants (Medicago truncatula, Lotus japonicus, Brachypodium distachyon) and major crops (e.g., maize, soybean, sorghum, tomato, pepper, cucumber, pea, wheat, banana, bean, rice, barley, Brassica napus). It seems now clear that these strategies are emerging as major crop improvement tools, with especially successful examples of recent applications to antiviral protection (Nieto et al., 2007; Piron et al., 2010).

\section{CHEMICAL TREATMENTS}

Curative treatments for virus control in fields is impossible. However, chemical applications can prime plant defense, i.e., resistance mechanisms are switched on prior to future infections. Based on the findings that exogenous applications of plant hormones trigger an efficient and broad-spectrum resistance to viral and non-viral pathogens, many SAR-priming molecules have been characterized. Among a series of SA analogs (Gozzo and Faoro, 2013), benzothiadiazole (BTH) has been identified as the safest and most efficient SAR activator and was brought to the market with the common name of acibenzolar-S-methyl, that leads to plant protection against many pathogens including viruses (Friedrich et al., 1996; Lawton et al., 1996; Mandal et al., 2008; Takeshita et al., 2013; Trejo-Saavedra etal., 2013). This priming approach represents an environment-friendly and efficient way to control plant diseases by exploiting a natural phenomenon. Despite these positive aspects, so far it has not yet been met with enthusiastic favor by the farmers, as the treatment efficacy with BTH (as well as other SAR-priming molecules) depends on many variables: dose, plant species and cultivar, growth stage of plant, pathogen pressure, climatic conditions and timing of chemical applications (Gozzo and Faoro, 2013). Nevertheless, coupled to genetic strategies, chemical SAR priming is still a valuable method to increase plant resistance against viruses for pest management programs in fields.

\section{PLANT VACCINATION}

Plant vaccination gambles on cross-protection, a phenomenon whereby the inoculation of a virus into a host plant prevents the multiplication of a subsequent challenge virus. This strategy mainly relies on the manipulation of the primary virus, whose infection is weak (symptomless with low viral load), and that triggers virus-induced gene silencing (VIGS) targeting both primary and challenge viruses (Ziebell and Carr, 2010; Nishiguchi and Kobayashi, 2011). Primary viruses act as vaccines and are classified into two categories: the attenuated and the engineering viruses. An attenuated virus corresponds to a weak isolate that triggers cross-protection against virulent isolates of the same virus or closed related viruses (Ziebell and Carr, 2010; Nishiguchi and Kobayashi, 2011). Many examples of cross-protection have been identified since the discovery of this phenomenon by McKinney in 1920s (McKinney, 1926; Crowdy and Posnette, 1947; Fletcher, 1978; Wang, 1991; Wen et al., 1991; Hugues and Ollennu, 1994; 
Valkonen et al., 2002; Kurihara and Watanabe, 2003; Ichiki et al., 2005; You et al., 2005; Kosaka et al., 2006; Yoon et al., 2006; Ziebell et al., 2007; Nakazono-Nagaoka et al., 2009; Kurth et al., 2012). A great illustration of this method involves an attenuated isolate of Zucchini yellow mosaic potyvirus, that has since been registered as the pesticide CUBIO ZY-02 and successfully employed in virus disease control in Japan (Kosaka and Fukunishi, 1997; Kosaka et al., 2009). Moreover, tristeza disease caused by CTV is currently controlled by mild CTV isolates, which when inoculated into existing field trees, extend the productive life of orchards and enable a more graduate replanting of trees on CTV-tolerant rootstocks (Lee and Keremane, 2013). However, identifying effective attenuated viruses for each virus of economical importance might be very arduous. A possible solution came recently from the development of engineering vaccines based on viral vectors carrying a genomic fragment of the virulent virus of interest (Culver, 1996; Bazzini et al., 2006; Tamura et al., 2013; Taki et al., 2013). Given Apple latent spherical cheravirus (ALSV) is able to infect a broad range of herbaceous crops (e.g., tomato, lettuce, zucchini, spinach, soybean, tobacco) and fruit trees (e.g., apple, cherry, peach, plum, pear, and citrus) without causing any symptoms, this virus was identified as an excellent candidate for VIGS-mediated vaccination, that could be simply applied widely by replacing the insert with a sequence derived from a different virus. This strategy has been recently illustrated (Tamura et al., 2013; Taki et al., 2013) and represents a very promising technology in virus epidemics management in fields.

\section{NEW RESEARCH LEAD: LET'S TALK ABOUT ANTIVIRAL PTI IN PLANTS}

In an attempt to increase resistance durability in fields, crop improvement requires a continuous pipeline of new resistance genes. Given the importance of PAMP-triggered immunity (PTI) in the field of pathology over the last decades, PTI against plant viruses represents an unexplored question that needs to be addressed.

\section{PLANT INNATE IMMUNITY}

Over the last decades, a concept revolutionizing the understanding of immunity emerged in plant pathology. This new concept stems from the ability for each organism to discriminate between self and non-self molecules through the action of pattern recognition receptors (PRRs) perceiving specific microbial molecular signatures, named pathogen-associated molecular patterns (PAMPs). Perception of PAMPs by these immune receptors induces a downstream signaling cascade including PRR association with positive regulators, phosphorylation events, successive activation of cytoplasmic kinases (including the MAP kinases) and defense-related transcription factors, as well as specific defense genes expression. This range of fast, efficient and multi-layered defense responses is referred as PTI (Nicaise et al., 2009; Macho and Zipfel, 2014). To counteract this defense strategy, successful pathogens deploy effectors proteins, the primary function of which is to evade/interfere with PTI. In turn, some plant cultivars have evolved R proteins to block these effectors, leading to effector-triggered immunity (ETI; Jones and Dangl, 2006). Because both PTI and ETI defense layers rely on cellular actors already present primary to the infection, they are commonly classified into plant innate immunity, in opposition to the concept of adaptive immunity (e.g., gene silencing), where the defense responses are acquired following an infection and are adapted to the pathogen.

\section{IT'S ALL ABOUT GOOD QUESTIONS}

To date, most current models about plant innate immunity exclude viruses, as they are not generally viewed as encoding typical PAMPs and effectors that would trigger PTI and ETI responses (Jones and Dangl, 2006; Boller and Felix, 2009; Schwessinger and Ronald, 2012; Dangl et al., 2013). The fact that virus biology differs greatly from other pathogens raises several questions of importance: could plants defend themselves against viral attacks through similar defense mechanisms employed against non-viral pathogens? And then, could the zig-zag model from Jones and Dangl (2006) be applied to plant-virus interactions?

Given that $R$ gene-based immunity in plant-virus interactions involves specific recognition of viral avirulence factors by hostencoded NBS-LRR proteins and leads to HR and SAR (described previously in this review), recent hypotheses advance that it may correspond to antiviral ETI mechanisms (Moffett, 2009; Mandadi and Scholthof, 2013; De Ronde et al., 2014; Nakahara and Masuta, 2014). If so, it may suggest that viral avirulent factors perceived by $\mathrm{R}$ proteins correspond to pathogenic effectors, the primary function being to target PTI. Therefore, the concept of antiviral innate immunity as a whole lies mainly in whether it exists virusassociated PRR pathways and viral-encoded effectors interfering with PTI responses. Therefore, the question to assess in priority is whether plant viruses possess molecular features meeting the definition of PAMPs.

\section{DO VIRUSES ENCODE PAMPs?}

Pathogen-associated molecular patterns are defined as highly conserved molecular signatures, characteristic of entire classes of microbes and with an essential function for these microbes (Medzhitov and Janeway, 1997), which implies that they are under strong evolutive pressure and thus, not easily modified by mutations. Many PAMPs from plant pathogens have been identified and so far, they are comprised of proteins, lipids, or carbohydrates (Boller and Felix, 2009). Virus genomes are highly variable even within the same viral family and display high mutation rates during the infection process ( $\geq 1$ mutation per genome per round of replication), making the expression "viral populations" more suitable than "viruses" when speaking of infected hosts. This elevated mutation rate allows viruses to quickly adapt to changes in their host or environment. Therefore, the PAMP definition referring to small molecular motifs conserved within a class of pathogen is hardly applicable to viral protein motifs. By contrast, virus genomes and their replicative forms (such as dsRNAs) display structural characteristics distinguishing them from the nucleic acid sequences from prokaryotes and eukaryotes. Consequently, these very conserved nucleic acids-composed features could be perceived as non-self signals in plants, acting thus as viral PAMPs.

\section{WHAT DO WE KNOW ABOUT PTI IN ANIMAL-VIRUS INTERACTIONS?}

In the animal field, the most prominent group of PRRs comprises the Toll-like receptors (TLRs), a family of a dozen type 
I-transmembrane proteins containing a domain with LRRs and a tail that contains a conserved region called Toll/IL-1 receptor (TIR) domain (Beutler, 2004), and sharing common recognition strategies and structural features with plant PRRs (Zipfel and Felix, 2005; Ronald and Beutler, 2010). The TLRs involved in antiviral PTI are localized in endosomes and perceive pathogen nucleic acids: TLR3 binds virus-derived dsRNA, TLR7 and TLR8 recognize viral single-stranded RNAs (ssRNA) and TLR9 mediates the perception of unmethylated $\mathrm{CpG}$ DNA from viruses (as well as bacteria and protozoa; Beutler, 2004). After PAMP perception, the activated receptor seems to form homo- and/or hetero-dimers with other TLRs. The TIR domains of these complexes recruit cytoplasmic adaptors, triggering a signaling cascade that mainly consist on the successive activation of cytoplasmic kinases including the MAP kinases, defense-related transcription factors and the expression of specific defense genes (Beutler, 2004; Kawai and Akira, 2008; Sandig and Bulfone-Paus, 2012). In addition, subsequent studies revealed that TLR-independent recognition of viruses can be also accomplished by cytosolic PRRs, including the two RNA helicases RIG-I (Retinoic acid-inducible gene I) and MDA5 (Melanoma differentiationassociated gene 5), both highly activated by dsRNAs, as well as $5^{\prime}$ triphosphate-RNAs for RIG-I (Kawai and Akira, 2008). In the arm race between host and microbes, successful animal viruses have evolved to suppress and/or hijack PTI responses, leading to host colonization. This overcoming of defense mechanisms is orchestrated by virulence effectors encoded by virus genomes. Among the strategies employed by viruses to suppress host immunity, inactivation of cytoplasmic kinases, inhibition of PRR complexes, stabilization of immunity-related negative regulators and inactivation of transcription factors are particularly noteworthy (Schröder and Bowie, 2007; Yokota etal., 2010).

\section{ON THE TRAIL OF PTI AGAINST PLANT VIRUSES}

The existence of animal PRRs specific to viral PAMPs raises the question of the existence of PRRs perceiving plant viruses. Although no PTI pathways against plant viruses has been formally characterized to date, typical PTI cellular responses are observed during plant-virus interactions, including ion fluxes (Shabala etal., 2010, 2011; Otulak and Garbaczewska, 2011), ROS production (Allan et al., 2001; Love etal., 2005; DíazVivancos et al., 2008), ethylene signaling (de Laat and van Loon, 1982; Love etal., 2005), and callose deposition (Iglesias and Meins, 2000; Li etal., 2012; Zavaliev etal., 2013). Key components of plant PTI pathways are also involved in antiviral defense mechanisms. SA, known to regulate innate immunity including PTI responses (Tsuda etal., 2008; Yi etal., 2014), plays an important role in plant-virus interactions (Carr et al., 2010). MAPK4, that regulates negatively plant PTI mechanisms (Gao et al., 2008; Kong et al., 2012), represses soybean defense against Bean pod mottle comovirus (Liu etal., 2011). The receptor-like kinases (RLKs) BAK1 (BRI1-Associated receptor Kinase 1) and BKK1 (BAK1-like Kinase 1), key activators of plant PRRs after PAMP perception (Kim et al., 2013), are required for Arabidopsis resistance to plant viruses (Yang et al., 2010; Kørner et al., 2013). Moreover, the protein NIK1, another
RLK highly similar to BAK1 and BKK1, has been strongly associated with Arabidopsis defense against the Cabbage leaf curl geminivirus (CaLCuV). Strikingly, NIK1 is cleaved by the viral protein NSP during the infection, suppressing its kinase activity and thus enhancing susceptibility to $\mathrm{CaLCuV}$ infection (Fontes etal., 2004; Carvalho etal., 2008). Overall, these data support the hypothesis that plants may defend themselves against viruses through similar PTI pathways employed against non-viral pathogens.

Accumulating data indicate that: (i) colonization strategies employed by plant and animal viruses inside host cells are highly similar (Thivierge et al., 2005; Taliansky et al., 2010; Nicholson and White, 2014), (ii) plant and animal PTI mechanisms display impressive structural and functional similarities (Zipfel and Felix, 2005; Dardick and Ronald, 2006; Ronald and Beutler, 2010), (iii) effectors from animal and plant pathogens target similar PTI components (Schröder and Bowie, 2007; Yokota et al., 2010; Deslandes and Rivas, 2012) and, (iv) plant defense against viruses involves many components belonging to PTI signaling (described above). Therefore, the apparent universality of PTI strategies identified so far in eukaryotic organisms enable an extrapolation of antiviral pathways from animal toward plant models.

Thus, strongly based on the understanding of plant immune pathways and the knowledge on antiviral mechanisms from the animal field, I propose here a model of plant immunity against viruses (Figure 3), that does not invalidate previous models but instead tries (i) to bring the concept of PTI as a novel plant antiviral mechanism, and (ii) to integrate the concept of innate (PTI and ETI) and adaptive (gene silencing) antiviral immunities, both triggered by similar virus-derived elicitor molecules, in order to address the important question of plant defense against viruses in a more holistic way.

Thus, following the virus entry into a plant cell, viral nucleic acids are perceived as PAMPs by specific intracellular PRRs triggering PTI pathways (Figure 3). Successful viruses encode specialized effectors that are able to suppress this defense layer. In turn, specific $R$ gene products interact with these effectors (playing then the role of avirulence factors), leading to ETI. In the case of RNAi-based adaptive immunity, the viral elicitor molecules (mostly dsRNAs) are recognized by DCLs. This leads to virus degradation at the nucleic acid level, a process that can be suppressed by a second class of virus-encoded effectors, commonly named silencing suppressors. Interestingly, Sansregret et al. (2013) recently highlighted a resistance mechanism antagonizing the silencing suppressor P19, through a phenomenon of extreme resistance characterized by a SA- and ethylene-dependent process without microscopic cell death. Although the reliance of this mechanism on one or several $\mathrm{R}$ proteins remains to be established, this data suggest that the action of RNAi-suppressing effectors might be countered by ETI-like mechanisms.

It is important to note here that recent reviews refer DCLs themselves as PRRs perceiving viral nucleic acids and triggering immune responses equivalent to the zig-zag model first layer (Pumplin and Voinnet, 2013; Sansregret et al., 2013; Nakahara and Masuta, 2014). Of course, PTI and RNAi mechanisms are both induced by highly similar virus-derived molecules that both fit the definition of PAMPs, suggesting that these virus-derived molecules 


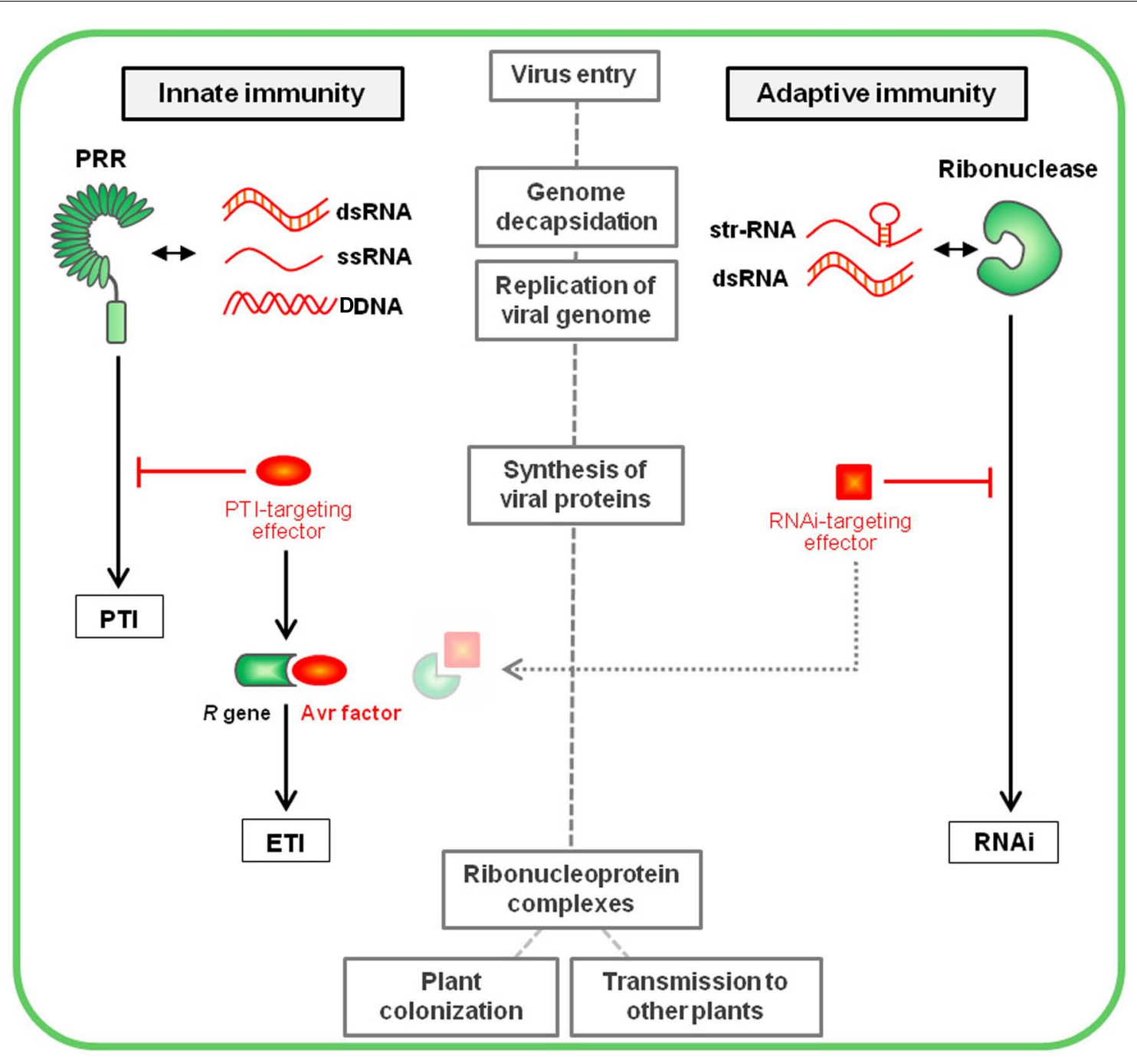

FIGURE 3 | Plant innate immunity vs. Plant adaptive immunity. Following entry into a host cell and genome decapsidation, the virus genome is liberated and replicated, leading to the accumulation of pathogenic nucleic acids that are perceived as viral PAMPs by specific intracellular PRRs. This recognition triggers a downstream cascade leading to PTI responses. Virus genome translation (occurring simultaneous to replication) leads to the synthesis of the virus-encoded proteins, among which viral pathogenic effectors enable the suppression of PTI signaling. In turn, specific plant $R$ genes interact (directly or indirectly) with these effectors (that are then called avirulence factors) to trigger ETI. In the case of plant adaptive immunity illustrated by RNA interference (RNAi), the virus-derived elicitor molecules, corresponding to replicative dsRNAs or structured (str-RNA) viral genomes, are recognized by DCLs, key component of the silencing machinery that leads to virus degradation at the nucleic acid level. Viral proteins acting as RNAi-suppressing effectors interfere with this defense pathway. A recent publication (Sansregret et al., 2013) suggests silencing suppressors may be targeted by ETI-like mechanisms, restoring plant resistance. The main steps of the virus cycle into the first infected cell have been mentioned into gray boxes. trigger two different pathways in parallel (PTI and RNAi), similarly as in the animal field (Yan and Chen, 2012). In line with this, DCL-mediated immunity should maybe be called PTI too. However, this idea faces a conceptual and semantic conflict, as the classical view of PTI lies on innate immunity, while silencing triggers an immunity that is classified as adaptive. This issue could be partially solved by raising the concepts of innate and adaptive PTIs, that both would be targeted by plant ETI. This notwithstanding, this situation reveals that these processes represents two distinct but tight and intricate branches of the whole plant immune arsenal against viruses, raising important conceptual questions that will need to be answered.
Indeed, future investigations will need first to bring the clear proof of the existence of PTI pathways triggered by the recognition of viral PAMPs by plant PRRs. To this perspective, the identification of pathogenic effectors from successful plant viruses that target specifically PTI responses will be definitely an asset, as pathogenic effectors represent fantastic molecular tools commonly used to characterize innate immunity signaling.

\section{WHICH ADVANTAGE PTI COULD BRING INTO CROP IMPROVEMENT PROGRAMS?}

So far, the only powerful strategy to control viral epidemics in field relies on the use of genetic resistances. Unfortunately, 
viruses evolve very quickly the ability to overcome the resistances employed by breeders. Hence, handling the extreme genetic plasticity of viruses represents a major challenge for the coming years. The durability of plant resistances, even more with viruses than any other plant pathogen, depends mostly on the resistance timing/efficiency and on the elicitor nature/conservation within pathogen families, in order to enable an efficient, sustainable, and broad-spectrum resistance.

Given their importance for pathogen survival, PAMPs are under a strong evolutive pressure and are highly conserved within pathogen families, this definition fitting perfectly with the characteristics of viral nucleic acids, whose features (e.g., dsRNAs replicative forms, highly structured genomes) are highly conserved within virus families and differ radically from prokaryotic or eukaryotic nucleic acids. It is these typical viral features that are perceived by specialized PRRs in animals (e.g., TLRs), triggering very fast and very efficient immune responses. Because the innate pathway is solely programmed by structural and nucleotide sequence genomic features, plant antiviral PTI should be a remarkably versatile mechanism because it could respond virtually to any plant virus. Moreover, timeliness of defense responses is a key parameter in resistance success, especially in the case of viruses, given their tremendous adaptation abilities. And yet, the first measurable PTI responses are within minutes after PAMP perception (Nicaise et al., 2009), making PTI the quickest plant defense identified so far. Hence, translating fundamental knowledge about PTI mechanisms for new crop resistance deployment must bring considerable advances in the control of viral epidemics in fields. Moreover, what is increasingly clear is that plant antiviral arsenal ensure a highly robust plant immune system, through different plant defense layers ( $\mathrm{R}$ genes, SAR, RNAi, PTI, and ETI) that emerge to be finely coordinated (Voinnet, 2005; Alamillo et al., 2006; Boccara etal., 2014; Padmanabhan and Dinesh-Kumar, 2014). Consequently, addressing plant-virus interactions holistically by combining PTI-mediated resistance with other defense pathways (such as silencing) could provide highly robust resistance phenotypes targeting virus cycle as a whole.

\section{CONCLUSION}

In the world agriculture context, intensification of cultural practices, climate alterations, and extensive exchanges affecting global markets are associated with an increased incidence of plant viral diseases. In consequence, management of viral epidemics is a matter of global food security. Nowadays, antiviral measures employed in fields benefits greatly from the latest knowledge highlighted by plant virologists, geneticists and molecular biologists, as well as engineers and breeders, whose coordinated effort enables a deployment in crop improvement programs. This notwithstanding, the situation in fields remains worrying, given the emergence of numerous crop diseases ascribed to viruses, a statement that could be aggravated in the future through climate changes that might affect strongly virus and organism-vectors populations in terms of magnitude, locations and dynamics (Anderson et al., 2004; Gautam et al., 2013). In a coordinated manner with technological advances, fundamental research needs to explore new scientific leads, deciphering more and more thoroughly the intricate molecular dialog between a plant virus and its host. Hence, future challenges associated to the management of crop viral diseases will rely mainly on integrated research actions with a view to translating fundamental understanding toward applied programs, and thus reducing the gap existing between the laboratory and the field.

\section{ACKNOWLEDGMENT}

This work was supported by the European Framework Programme 7, through a Marie-Curie Intra-European Fellowship (Grant number 327341).

\section{REFERENCES}

Abel, P. P., Nelson, R. S., De, B., Hoffmann, N., Rogers, S. G., Fraley, R. T., etal. (1986). Delay of disease development in transgenic plants that express the tobacco mosaic virus coat protein gene. Science 232, 738-743. doi: $10.1126 /$ science. 3457472

Abo, M. E., and Sy, A. A. (1998). Rice virus diseases: epidemiology and management strategies. J. Sustain. Agric. 11, 113-134. doi: 10.1300/J064v11n02_09

Acosta-Leal, R., and Xiong, Z. (2008). Complementary functions of two recessive R-genes determine resistance durability of tobacco "Virgin A Mutant" (VAM) to potato virus Y. Virology 379, 275-283. doi: 10.1016/j.virol.2008.06.026

Akbergenov, R., Si-Ammour, A., Blevins, T., Amin, I., Kutter, C., Vanderschuren, H., et al. (2006). Molecular characterization of geminivirus-derived small RNAs in different plant species. Nucleic Acids Res. 34, 462-471. doi: 10.1093/nar/ gkj447

Alamillo, J. M., Saénz, P., and García, J. A. (2006). Salicylic acid-mediated and RNA-silencing defense mechanisms cooperate in the restriction of systemic spread of plum pox virus in tobacco. Plant J. 48, 217-227. doi: 10.1111/j.1365-313X.2006.02861.x

Alazem, M., Lin, K.-Y., and Lin, N.-S. (2014). The abscisic acid pathway has multifaceted effects on the accumulation of bamboo mosaic virus. Mol. Plant Microbe Interact. 27, 177-189. doi: 10.1094/MPMI-08-13-0216-R

Ali, S. S., Gunupuru, L. R., Kumar, G. B., Khan, M., Scofield, S., Nicholson, P., et al. (2014). Plant disease resistance is augmented in uzu barley lines modified in the brassinosteroid receptor BRI1. BMC Plant Biol. 14:227. doi: 10.1186/s12870-0140227-1

Allan, A. C., Lapidot, M., Culver, J. N., and Fluhr, R. (2001). An early tobacco mosaic virus-induced oxidative burst in tobacco indicates extracellular perception of the virus coat protein. Plant Physiol. 126, 97-108. doi: 10.1104/pp.126.1.97

Anderson, P. K., Cunningham, A. A., Patel, N. G., Morales, F. J., Epstein, P. R., and Daszak, P. (2004). Emerging infectious diseases of plants: pathogen pollution, climate change and agrotechnology drivers. Trends Ecol. Evol. 19, 535-544. doi: 10.1016/j.tree.2004.07.021

Aragão, F. J. L., Nogueira, E. O., Tinoco, M. L., and Faria, J. C. (2013). Molecular characterization of the first commercial transgenic common bean immune to the bean golden mosaic virus. J. Biotechnol. 166, 42-50. doi: 10.1016/j.jbiotec.2013.04.009 Aregger, M., Borah, B. K., Seguin, J., Rajeswaran, R., Gubaeva, E. G., Zvereva, A. S., et al. (2012). Primary and secondary siRNAs in geminivirus-induced gene silencing. PLoS Pathog. 8:e1002941. doi: 10.1371/journal.ppat.1002941

Azevedo, C., Betsuyaku, S., Peart, J., Takahashi, A., Noël, L., Sadanandom, A., et al. (2006). Role of SGT1 in resistance protein accumulation in plant immunity. EMBO J. 25, 2007-2016. doi: 10.1038/sj.emboj.7601084

Azevedo, J., Garcia, D., Pontier, D., Ohnesorge, S., Yu, A., Garcia, S., et al. (2010). Argonaute quenching and global changes in Dicer homeostasis caused by a pathogen-encoded GW repeat protein. Genes Dev. 24, 904-915. doi: $10.1101 /$ gad. 1908710

Bai, S., Liu, J., Chang, C., Zhang, L., Maekawa, T., Wang, Q., et al. (2012). Structure-function analysis of barley NLR immune receptor MLA10 reveals its cell compartment specific activity in cell death and disease resistance. PLoS Pathog. 8:e1002752. doi: 10.1371/journal.ppat.1002752

Barajas, D., Martín, I. F., Pogany, J., Risco, C., and Nagy, P. D. (2014a). Noncanonical role for the host Vps4 AAA+ ATPase ESCRT protein in the formation of tomato bushy stunt virus replicase. PLoS Pathog. 10:e1004087. doi: 10.1371/journal.ppat.1004087

Barajas, D., Xu, K., de Castro Martín, I. F., Sasvari, Z., Brandizzi, F., Risco, C., et al. (2014b). Co-opted oxysterol-binding ORP and VAP proteins channel sterols to 
RNA virus replication sites via membrane contact sites. PLoS Pathog. 10:e1004388. doi: 10.1371/journal.ppat.1004388

Baurès, I., Candresse, T., Leveau, A., Bendahmane, A., and Sturbois, B. (2008). The $\mathrm{Rx}$ gene confers resistance to a range of potexviruses in transgenic Nicotiana plants. Mol. Plant Microbe Interact. 21, 1154-1164. doi: 10.1094/MPMI-219-1154

Bazzini, A. A., Asurmendi, S., Hopp, H. E., and Beachy, R. N. (2006). Tobacco mosaic virus (TMV) and potato virus X (PVX) coat proteins confer heterologous interference to PVX and TMV infection, respectively. J. Gen. Virol. 87, 1005-1012. doi: 10.1099/vir.0.81396-0

Bendahmane, A., Kanyuka, K., and Baulcombe, D. C. (1999). The Rx gene from potato controls separate virus resistance and cell death responses. Plant Cell 11, 781-792. doi: 10.1105/tpc.11.5.781

Beutler, B. (2004). Innate immunity: an overview. Mol. Immunol. 40, 845-859. doi: 10.1016/j.molimm.2003.10.005

Blevins, T., Rajeswaran, R., Aregger, M., Borah, B. K., Schepetilnikov, M., Baerlocher L., et al. (2011). Massive production of small RNAs from a non-coding region of cauliflower mosaic virus in plant defense and viral counter-defense. Nucleic Acids Res. 39, 5003-5014. doi: 10.1093/nar/gkr119

Blevins, T., Rajeswaran, R., Shivaprasad, P. V., Beknazariants, D., Si-Ammour, A., Park, H. S., et al. (2006). Four plant Dicers mediate viral small RNA biogenesis and DNA virus induced silencing. Nucleic Acids Res. 34, 6233-6246. doi: 10.1093/nar/gkl886

Boccara, M., Sarazin, A., Thiébeauld, O., Jay, F., Voinnet, O., Navarro, L., et al. (2014). The Arabidopsis miR472-RDR6 silencing pathway modulates PAMPand effector-triggered immunity through the post-transcriptional control of disease resistance genes. PLoS Pathog. 10:e1003883. doi: 10.1371/journal.ppat. 1003883

Boller, T., and Felix, G. (2009). A renaissance of elicitors: perception of microbe-associated molecular patterns and danger signals by pattern-recognition receptors. Annu. Rev. Plant Biol. 60, 379-406. doi: 10.1146/annurev.arplant. 57.032905.105346

Bologna, N. G., and Voinnet, O. (2014). The diversity, biogenesis, and activities of endogenous silencing small RNAs in Arabidopsis. Annu. Rev. Plant Biol. 65, 473-503. doi: 10.1146/annurev-arplant-050213-035728

Boonham, N., Kreuze, J., Winter, S., van der Vlugt, R., Bergervoet, J., Tomlinson, J., et al. (2014). Methods in virus diagnostics: from ELISA to next generation sequencing. Virus Res. 186, 20-31. doi: 10.1016/j.virusres.2013.12.007

Botër, M., Amigues, B., Peart, J., Breuer, C., Kadota, Y., Casais, C., et al. (2007). Structural and functional analysis of SGT1 reveals that its interaction with HSP90 is required for the accumulation of $\mathrm{Rx}$, an $\mathrm{R}$ protein involved in plant immunity. Plant Cell 19, 3791-3804. doi: 10.1105/tpc.107.050427

Bragard, C., Caciagli, P., Lemaire, O., Lopez-Moya, J. J., MacFarlane, S., Peters, D., et al. (2013). Status and prospects of plant virus control through interference with vector transmission. Annu. Rev. Phytopathol. 51, 177-201. doi: 10.1146/annurevphyto-082712-102346

Bravo-Almonacid, F., Rudoy, V., Welin, B., Segretin, M. E., Bedogni, M. C., Stolowicz, F., et al. (2012). Field testing, gene flow assessment and pre-commercial studies on transgenic Solanum tuberosum spp. tuberosum (cv. Spunta) selected for PVY resistance in Argentina. Transgenic Res. 21, 967-982. doi: 10.1007/s11248-0119584-9

Burgyán, J., and Havelda, Z. (2011). Viral suppressors of RNA silencing. Trends Plant Sci. 16, 265-272. doi: 10.1016/j.tplants.2011.02.010

Calvert, L. A., and Tresh, J. M. (2002). “The viruses and virus diseases of cassava," in Cassava: Biology, Production and Utilization, eds R. J. Hillocks, J. M. Thresh, and A. C. Bellotti (Wallingford: CABI Publishing).

Cambra, M., Capote, N., Myrta, A., and Llácer, G. (2006). Plum pox virus and the estimated costs associated with sharka disease. EPPO Bull. 36, 202-204. doi: 10.1111/j.1365-2338.2006.01027.x

Candresse, T., Marais, A., Faure, C., Dubrana, M. P., Gombert, J., and Bendahmane, A. (2010). Multiple coat protein mutations abolish recognition of Pepino mosaic potexvirus (PepMV) by the potato rx resistance gene in transgenic tomatoes. Mol. Plant Microbe Interact. 23, 376-383. doi: 10.1094/MPMI-234-0376

Caplan, J. L., Mamillapalli, P., Burch-Smith, T. M., Czymmek, K., and Dinesh-Kumar, S. P. (2008). Chloroplastic protein NRIP1 mediates innate immune receptor recognition of a viral effector. Cell 132, 449-462. doi: 10.1016/j.cell.2007.12.031
Caranta, C., Lefebvre, V., and Palloix, A. (1997). Polygenic resistance of pepper to potyviruses consists of a combination of isolate-specific and broadspectrum quantitative trait loci. Mol. Plant Microbe Interact. 10, 872-878. doi: 10.1094/MPMI.1997.10.7.872

Carr, J. P., Lewsey, M. G., and Palukaitis, P. (2010). Signaling in induced resistance. Adv. Virus Res. 76, 57-121. doi: 10.1016/S0065-3527(10)76003-6

Carvalho, C. M., Santos, A. A., Pires, S. R., Rocha, C. S., Saraiva, D. I., Machado, J. P. B., et al. (2008). Regulated nuclear trafficking of rpL10A mediated by NIK1 represents a defense strategy of plant cells against virus. PLoS Pathog. 4:e1000247. doi: 10.1371/journal.ppat.1000247

Cavatorta, J., Perez, K. W., Gray, S. M., Van Eck, J., Yeam, I., and Jahn, M. (2011). Engineering virus resistance using a modified potato gene. Plant Biotechnol. J. 9, 1014-1021. doi: 10.1111/j.1467-7652.2011.00622.x

Charron, C., Nicolaï, M., Gallois, J. L., Robaglia, C., Moury, B., Palloix, A., et al. (2008). Natural variation and functional analyses provide evidence for co-evolution between plant eIF4E and potyviral VPg. Plant J. 54, 56-68. doi: 10.1111/j.1365-313X.2008.03407.x

Chen, L., Zhang, L., Li, D., Wang, F., and Yu, D. (2013). WRKY8 transcription factor functions in the TMV-cg defense response by mediating both abscisic acid and ethylene signaling in Arabidopsis. Proc. Natl. Acad. Sci. U.S.A. 110, E1963-E1971. doi: 10.1073/pnas.1221347110

Collard, B. C. Y., and Mackill, D. J. (2008). Marker-assisted selection: an approach for precision plant breeding in the twenty-first century. Philos. Trans. R. Soc. Lond. B Biol. Sci. 363, 557-572. doi: 10.1098/rstb.2007.2170

Comai, L., Young, K., Till, B. J., Reynolds, S. H., Greene, E. A., Codomo, C. A., et al. (2004). Efficient discovery of DNA polymorphisms in natural populations by Ecotilling. Plant J. 37, 778-786. doi: 10.1111/j.0960-7412.2003.01999.x

Cosson, P., Schurdi-Levraud, V., Le, Q. H., Sicard, O., Caballero, M., Roux, F., et al. (2012). The RTM resistance to potyviruses in Arabidopsis thaliana: natural variation of the RTM genes and evidence for the implication of additional genes. PLoS ONE 7:e39169. doi: 10.1371/journal.pone.0039169

Cosson, P., Sofer, L., Le, Q. H., Léger, V., Schurdi-Levraud, V., Whitham, S. A., etal. (2010a). RTM3, which controls long-distance movement of potyviruses, is a member of a new plant gene family encoding a meprin and TRAF homology domain-containing protein. Plant Physiol. 154, 222-232. doi: 10.1104/pp.110.155754

Cosson, P., Sofer, L., Schurdi-Levraud, V., and Revers, F. (2010b). A member of a new plant gene family encoding a meprin and TRAF homology (MATH) domaincontaining protein is involved in restriction of long distance movement of plant viruses. Plant Signal. Behav. 5, 1321-1323. doi: 10.4161/psb.5.10.13244

Crowdy, S. H., and Posnette, A. F. (1947). Virus diseases of cacao in West Africa II. Cross immunity experiments with viruses 1A, 1B and 1C. Ann. Appl. Biol. 34, 403-411. doi: 10.1111/j.1744-7348.1947.tb06373.x

Culver, J. N. (1996). Tobamovirus cross protection using a potexvirus vector. Virology 226, 228-235. doi: 10.1006/viro.1996.0650

Dangl, J. L., Horvath, D. M., and Staskawicz, B. J. (2013). Pivoting the plant immune system from dissection to deployment. Science 341, 746-751. doi: $10.1126 /$ science. 1236011

Dardick, C., and Ronald, P. (2006). Plant and animal pathogen recognition receptors signal through non-RD kinases. PLoS Pathog. 2:e2. doi: 10.1371/journal.ppat.0020002

Decroocq, V., Sicard, O., Alamillo, J. M., Lansac, M., Eyquard, J. P., García, J. A., et al. (2006). Multiple resistance traits control plum pox virus infection in Arabidopsis thaliana. Mol. Plant Microbe Interact. 19, 541-549. doi: 10.1094/MPMI-19-0541

de Laat, A. M. M., and van Loon, L. C. (1982). Regulation of ethylene biosynthesis in virus-infected tobacco leaves 1. Plant Physiol. 69, 240-245. doi: 10.1104/pp.69.1.240

Delaney, T. P., Uknes, S., Vernooij, B., Friedrich, L., Weymann, K., Negrotto, D., et al. (1994). A central role of salicylic acid in plant disease resistance. Science 266, 1247-1250. doi: 10.1126/science.266.5188.1247

Deleris, A., Gallego-Bartolome, J., Bao, J., Kasschau, K. D., Carrington, J. C., and Voinnet, O. (2006). Hierarchical action and inhibition of plant Dicer-like proteins in antiviral defense. Science 313, 68-71. doi: 10.1126/science.1128214

Dempsey, D. A., and Klessig, D. F. (2012). SOS - too many signals for systemic acquired resistance? Trends Plant Sci. 17, 538-545. doi: 10.1016/j.tplants.2012.05.011

De Ronde, D., Butterbach, P., and Kormelink, R. (2014). Dominant resistance against plant viruses. Front. Plant Sci. 5:307. doi: 10.3389/fpls.2014.00307 
Deslandes, L., and Rivas, S. (2012). Catch me if you can: bacterial effectors and plant targets. Trends Plant Sci. 17, 644-655. doi: 10.1016/j.tplants.2012.06.011

Diaz, A., Wang, X., and Ahlquist, P. (2010). Membrane-shaping host reticulon proteins play crucial roles in viral RNA replication compartment formation and function. Proc. Natl. Acad. Sci. U.S.A. 107, 16291-16296. doi: 10.1073/pnas. 1011105107

Diaz-Pendon, J. A., Li, F., Li, W.-X., and Ding, S.-W. (2007). Suppression of antiviral silencing by cucumber mosaic virus $2 \mathrm{~b}$ protein in Arabidopsis is associated with drastically reduced accumulation of three classes of viral small interfering RNAs. Plant Cell 19, 2053-2063. doi: 10.1105/tpc.106.047449

Diaz-Pendon, J. A., Truniger, V., Nieto, C., Garcia-Mas, J., Bendahmane, A., and Aranda, M. A. (2004). Advances in understanding recessive resistance to plant viruses. Mol. Plant Pathol. 5, 223-233. doi: 10.1111/J.1364-3703.2004.00223.X

Díaz-Vivancos, P., Clemente-Moreno, M. J., Rubio, M., Olmos, E., García, J. A., Martínez-Gómez, P., et al. (2008). Alteration in the chloroplastic metabolism leads to ROS accumulation in pea plants in response to plum pox virus. J. Exp. Bot. 59, 2147-2160. doi: 10.1093/jxb/ern082

Dzahini-Obiatey, H., Domfeh, O., and Amoah, F. M. (2010). Over seventy years of a viral disease of cocoa in Ghana: from researchers' perspective. Afr. J. Agric. Res. 5, 476-485. doi: 10.5897/AJAR09.625

Elena, S. F., Bedhomme, S., Carrasco, P., Cuevas, J. M., de la Iglesia, F., Lafforgue, G., et al. (2011). The evolutionary genetics of emerging plant RNA viruses. Mol. Plant Microbe Interact. 24, 287-293. doi: 10.1094/MPMI-09-10-0214

Fabre, F., Rousseau, E., Mailleret, L., and Moury, B. (2012). Durable strategies to deploy plant resistance in agricultural landscapes. New Phytol. 193, 1064-1075. doi: 10.1111/j.1469-8137.2011.04019.x

Ferreira, S. A., Pitz, K. Y., Manshardt, R., Zee, F., Fitch, M., and Gonsalves, D. (2002), Virus coat protein transgenic papaya provides practical control of papaya ringspot virus in Hawaii. Plant Dis. 86, 101-105. doi: 10.1094/PDIS.2002.86.2.101

Fischer, U., and Dröge-Laser, W. (2004). Overexpression of NtERF5, a new member of the tobacco ethylene response transcription factor family enhances resistance to tobacco mosaic virus. Mol. Plant Microbe Interact. 17, 1162-1171. doi: 10.1094/MPMI.2004.17.10.1162

Fletcher, J. T. (1978). The use of avirulent virus strain to protect plants against the effects of virulent strains. Ann. Appl. Biol. 89, 110-114. doi: 10.1111/j.17447348.1978.tb02581.x

Fontes, E. P. B., Santos, A. A., Luz, D. F., Waclawovsky, A. J., and Chory, J. (2004). The geminivirus nuclear shuttle protein is a virulence factor that suppresses transmembrane receptor kinase activity. Genes Dev. 18, 2545-2556. doi: 10.1101/gad.1245904

Friedrich, L., Lawton, K., Ruess, W., Masner, P., Specker, N., Rella, M. G., et al. (1996). A benzothiadiazole derivative induces systemic acquired resistance in tobacco. Plant J. 10, 61-70. doi: 10.1046/j.1365-313X.1996.10010061.x

$\mathrm{Fu}, \mathrm{Z}$. Q., and Dong, X. (2013). Systemic acquired resistance: turning local infection into global defense. Annu. Rev. Plant Biol. 64, 839-863. doi: 10.1146/annurevarplant-042811-105606

Gao, M., Liu, J., Bi, D., Zhang, Z., Cheng, F., Chen, S., et al. (2008). MEKK1, MKK1/MKK2 and MPK4 function together in a mitogen-activated protein kinase cascade to regulate innate immunity in plants. Cell Res. 18, 1190-1198. doi: $10.1038 / \mathrm{cr} .2008 .300$

García-Arenal, F., and McDonald, B. A. (2003). An analysis of the durability of resistance to plant viruses. Phytopathology 93, 941-952. doi: 10.1094/PHYTO.2003.93.8.941

Garcia-Ruiz, H., Takeda, A., Chapman, E. J., Sullivan, C. M., Fahlgren, N., Brempelis, K. J., et al. (2010). Arabidopsis RNA-dependent RNA polymerases and dicer-like proteins in antiviral defense and small interfering RNA biogenesis during turnip mosaic virus infection. Plant Cell 22, 481-496. doi: 10.1105/tpc.109.073056

Gautam, H. R., Bhardwaj, M. L., and Kumar, R. (2013). Climate change and its impact on plant diseases. Curr. Sci. 105, 1685-1691.

Gozzo, F., and Faoro, F. (2013). Systemic acquired resistance (50 years after discovery): moving from the lab to the field. J. Agric. Food Chem. 61, 12473-12491. doi: $10.1021 / \mathrm{jf} 404156 \mathrm{x}$

Hämäläinen, J. H., Kekarainen, T., Gebhardt, C., Watanabe, K. N., and Valkonen, J. P. (2000). Recessive and dominant genes interfere with the vascular transport of potato virus a in diploid potatoes. Mol. Plant Microbe Interact. 13, 402-412. doi: 10.1094/MPMI.2000.13.4.402

Hao, W., Collier, S. M., Moffett, P., and Chai, J. (2013). Structural basis for the interaction between the potato virus $\mathrm{X}$ resistance protein $(\mathrm{Rx})$ and its cofactor
Ran GTPase-activating protein 2 (RanGAP2). J. Biol. Chem. 288, 35868-35876. doi: 10.1074/jbc.M113.517417

Harper, S. J. (2013). Citrus tristeza virus: evolution of complex and varied genotypic groups. Front. Microbiol. 4:93. doi: 10.3389/fmicb.2013.00093

Harvey, J. J. W., Lewsey, M. G., Patel, K., Westwood, J., Heimstädt, S., Carr, J. P., et al. (2011). An antiviral defense role of AGO2 in plants. PLoS ONE 6:e14639. doi: 10.1371/journal.pone.0014639

Hashmi, J. A., Zafar, Y., Arshad, M., Mansoor, S., and Asad, S. (2011). Engineering cotton (Gossypium hirsutum $\mathrm{L}$.) for resistance to cotton leaf curl disease using viral truncated AC1 DNA sequences. Virus Genes 42, 286-296. doi: 10.1007/s11262011-0569-9

Hoser, R., Zurczak, M., Lichocka, M., Zuzga, S., Dadlez, M., Samuel, M. A., et al. (2013). Nucleocytoplasmic partitioning of tobacco $\mathrm{N}$ receptor is modulated by SGT1. New Phytol. 200, 158-171. doi: 10.1111/nph.12347

Hugues, J. A., and Ollennu, L. A. A. (1994). Mild strain protection of cocoa in Ghana against cocoa swollen shoot virus-a review. Plant Pathol. 43, 442-457. doi: 10.1111/j.1365-3059.1994.tb01578.x

Hull, R. (2013). Plant Virology, 5th Edn. New York: Academic Press.

Hwang, J., Oh, C. S., and Kang, B. C. (2013). Translation elongation factor 1B (eEF1B) is an essential host factor for tobacco mosaic virus infection in plants. Virology 439, 105-114. doi: 10.1016/j.virol.2013.02.004

Hyodo, K., Mine, A., Taniguchi, T., Kaido, M., Mise, K., Taniguchi, H., et al. (2013). ADP ribosylation factor 1 plays an essential role in the replication of a plant RNA virus. J. Virol. 87, 163-176. doi: 10.1128/JVI.02383-12

Ichiki, T. U., Nagaoka, E. N., Hagiwara, K., Uchikawa, K., Tsuda, S., and Omura, T. (2005). Integration of mutations responsible for the attenuated phenotype of pepper mild mottle virus strains results in a symptomless cross-protecting strain. Arch. Virol. 150, 2009-2020. doi: 10.1007/s00705-005-0551-8

Iglesias, V. A., and Meins, F. (2000). Movement of plant viruses is delayed in a beta1,3-glucanase-deficient mutant showing a reduced plasmodesmatal size exclusion limit and enhanced callose deposition. Plant J. 21, 157-166. doi: 10.1046/j.1365313X.2000.00658.x

Ishibashi, K., and Ishikawa, M. (2013). The resistance protein Tm-1 inhibits formation of a tomato mosaic virus replication protein-host membrane protein complex. J. Virol. 87, 7933-7939. doi: 10.1128/JVI.00743-13

Ishibashi, K., Miyashita, S., Katoh, E., and Ishikawa, M. (2012). Host membrane proteins involved in the replication of tobamovirus RNA. Curr. Opin. Virol. 2, 693-698. doi: 10.1016/j.coviro.2012.09.011

Jakubiec, A., Yang, S. W., and Chua, N. H. (2012). Arabidopsis DRB4 protein in antiviral defense against turnip yellow mosaic virus infection. Plant J. 69, 14-25. doi: 10.1111/j.1365-313X.2011.04765.x

Jaubert, M., Bhattacharjee, S., Mello, A. F. S., Perry, K. L., and Moffett, P. (2011). ARGONAUTE2 mediates RNA-silencing antiviral defenses against potato virus X in Arabidopsis. Plant Physiol. 156, 1556-1564. doi: 10.1104/pp.111. 178012

Jiang, L., Qian, D., Zheng, H., Meng, L. Y., Chen, J., Le, W. J., et al. (2012). RNAdependent RNA polymerase 6 of rice (Oryza sativa) plays role in host defense against negative-strand RNA virus, rice stripe virus. Virus Res. 163, 512-519. doi: 10.1016/j.virusres.2011.11.016

Jones, J. D. G., and Dangl, J. L. (2006). The plant immune system. Nature 444, 323-329. doi: 10.1038/nature05286

Julio, E., Cotucheau, J., Decorps, C., Volpatti, R., Sentenac, C., Candresse, T., et al. (2014). A eukaryotic translation initiation factor $4 \mathrm{E}$ (eIF4E) is responsible for the "va" tobacco recessive resistance to potyviruses. Plant Mol. Biol. Rep. doi: 10.1007/s11105-014-0775-4

Kadota, Y., and Shirasu, K. (2012). The HSP90 complex of plants. Biochim. Biophys. Acta 1823, 689-97. doi: 10.1016/j.bbamcr.2011.09.016

Kang, B. C., Yeam, I., Li, H., Perez, K. W., and Jahn, M. M. (2007). Ectopic expression of a recessive resistance gene generates dominant potyvirus resistance in plants. Plant Biotechnol. J. 5, 526-536. doi: 10.1111/j.1467-7652.2007. 00262.x

Kawai, T., and Akira, S. (2008). Toll-like receptor and RIG-I-like receptor signaling. Ann. N. Y. Acad. Sci. 1143, 1-20. doi: 10.1196/annals.1443.020

Kazan, K., and Lyons, R. (2014). Intervention of phytohormone pathways by pathogen effectors. Plant Cell 26, 2285-2309. doi: 10.1105/tpc.114.125419

Kim, B. H., Kim, S. Y., and Nam, K. H. (2013). Assessing the diverse functions of BAK1 and its homologs in Arabidopsis, beyond BR signaling and PTI responses. Mol. Cells 35, 7-16. doi: 10.1007/s10059-013-2255-3 
King, A. M. Q., Adams, M. J., Carstens, E. B., and Lefkowitz, E. (2012). Virus Taxonomy: Classification and Nomenclature of Viruses: Ninth Report of the International Committee on Taxonomy of Viruses. San Diego: Elsevier Academic Press.

Kobayashi, M., Seo, S., Hirai, K., Yamamoto-Katou, A., Katou, S., Seto, H., et al. (2010). Silencing of WIPK and SIPK mitogen-activated protein kinases reduces tobacco mosaic virus accumulation but permits systemic viral movement in tobacco possessing the $\mathrm{N}$ resistance gene. Mol. Plant Microbe Interact. 23, 1032-1041. doi: 10.1094/MPMI-23-8-1032

Kong, Q., Qu, N., Gao, M., Zhang, Z., Ding, X., Yang, F., et al. (2012). The MEKK1MKK1/MKK2-MPK4 kinase cascade negatively regulates immunity mediated by a mitogen-activated protein kinase kinase kinase in Arabidopsis. Plant Cell 24, 2225-2236. doi: 10.1105/tpc.112.097253

Kørner, C. J., Klauser, D., Niehl, A., Domínguez-Ferreras, A., Chinchilla, D., Boller, T., et al. (2013). The immunity regulator BAK1 contributes to resistance against diverse RNA viruses. Mol. Plant Microbe Interact. 26, 1271-1280. doi: 10.1094/MPMI-06-13-0179-R

Kosaka, Y., and Fukunishi, T. (1997). Multiple inoculation with three attenuated viruses for the control of cucumber virus disease. Plant Dis. 81, 733-738. doi 10.1094/PDIS.1997.81.7.733

Kosaka, Y., Ryang, B.-S., Katagiri, N., and Yasuhara, H. (2009). "Development and diffusion of CUBIO ZY-02, a water-soluble formulation of an attenuated zucchini yellow mosaic virus isolate, for the control of cucumber mosaic disease," in Proceedings of PSJ Biocontrol Workshop, Vol. 11, Yamagata, 63-72.

Kosaka, Y., Ryang, B.-S., Kobori, T., Shiomi, H., Yasuhara, H., and Kataoka, M. (2006). Effectiveness of an attenuated Zucchini yellow mosaic virus isolate for cross-protecting cucumber. Plant Dis. 90, 67-72. doi: 10.1094/PD-90-0067

Kurihara, Y., and Watanabe, Y. (2003). Cross-protection in Arabidopsis against crucifer tobamovirus $\mathrm{Cg}$ by an attenuated strain of the virus. Mol. Plant Pathol. 4 259-269. doi: 10.1046/j.1364-3703.2003.00174.x

Kurth, E. G., Peremyslov, V. V., Prokhnevsky, A. I., Kasschau, K. D., Miller, M., Carrington, J. C., et al. (2012). Virus-derived gene expression and RNA interference vector for grapevine. J. Virol. 86, 6002-6009. doi: 10.1128/JVI.00436-12

Lawton, K. A., Friedrich, L., Hunt, M., Weymann, K., Delaney, T., Kessmann, H., et al. (1996). Benzothiadiazole induces disease resistance in Arabidopsis by activation of the systemic acquired resistance signal transduction pathway. Plant J. 10, 71-82. doi: 10.1046/j.1365-313X.1996.10010071.x

Lee, R. F., and Keremane, M. L. (2013). Mild strain cross protection of tristeza: a review of research to protect against decline on sour orange in Florida. Front. Microbiol. 4:259. doi: 10.3389/fmicb.2013.00259

Legg, J. P. (1999). Emergence, spread and strategies for controlling the pandemic of cassava mosaic virus disease in east and central Africa. Crop Prot. 18, 627-637. doi: 10.1016/S0261-2194(99)00062-9

Legg, J. P., and Thresh, J. M. (2000). Cassava mosaic virus disease in East Africa: a dynamic disease in a changing environment. Virus Res. 71, 135-149. doi 10.1016/S0168-1702(00)00194-5

Lemgo, G. N. Y., Sabbadini, S., Pandolfini, T., and Mezzetti, B. (2013) Biosafety considerations of RNAi-mediated virus resistance in fruit-tree cultivars and in rootstock. Transgenic Res. 22, 1073-1088. doi: 10.1007/s11248-0139728-1

Li, F., Huang, C., Li, Z., and Zhou, X. (2014a). Suppression of RNA silencing by a plant DNA virus satellite requires a host calmodulin-like protein to repress RDR6 expression. PLoS Pathog. 10:e1003921. doi: 10.1371/journal.ppat.1003921

Li, Z., Gonzalez, P. A., Sasvari, Z., Kinzy, T. G., and Nagy, P. D. (2014b). Methylation of translation elongation factor 1A by the METTL10-like See1 methyltransferase facilitates tombusvirus replication in yeast and plants. Virology 448, 43-54. doi 10.1016/j.virol.2013.09.012

Li, W., Zhao, Y., Liu, C., Yao, G., Wu, S., Hou, C., et al. (2012). Callose deposition at plasmodesmata is a critical factor in restricting the cell-to-cell movement of soybean mosaic virus. Plant Cell Rep. 31, 905-916. doi: 10.1007/s00299-0111211-y

Lin, C. Y., Ku, H. M., Chiang, Y. H., Ho, H. Y., Yu, T. A., and Jan, F. J. (2012). Development of transgenic watermelon resistant to cucumber mosaic virus and watermelon mosaic virus by using a single chimeric transgene construct. Transgenic Res. 21, 983-993. doi: 10.1007/s11248-011-9585-8

Liu, J.-Z., Horstman, H. D., Braun, E., Graham, M. A., Zhang, C., Navarre, D., et al. (2011). Soybean homologs of MPK4 negatively regulate defense responses and positively regulate growth and development. Plant Physiol. 157, 1363-1378. doi: $10.1104 /$ pp.111.185686
Liu, P.-P., Yang, Y., Pichersky, E., and Klessig, D. F. (2010). Altering expression of benzoic acid/salicylic acid carboxyl methyltransferase 1 compromises systemic acquired resistance and PAMP-triggered immunity in Arabidopsis. Mol. Plant Microbe Interact. 23, 82-90. doi: 10.1094/MPMI-23-1-0082

Liu, Y., Schiff, M., Marathe, R., and Dinesh-Kumar, S. P. (2002). Tobacco Rar1, EDS1 and NPR1/NIM1 like genes are required for N-mediated resistance to tobacco mosaic virus. Plant J. 30, 415-429. doi: 10.1046/j.1365-313X.2002.01297.x

Lius, S., Manshardt, R. M., Fitch, M. M. M., Slightom, J. L., Sanford, J. C., and Gonsalves, D. (1997). Pathogen-derived resistance provides papaya with effective protection against papaya ringspot virus. Mol. Breed. 3, 161-168. doi: 10.1023/A:1009614508659

Love, A. J., Laval, V., Geri, C., Laird, J., Tomos, A. D., Hooks, M. A., et al. (2007). Components of Arabidopsis defense- and ethylene-signaling pathways regulate susceptibility to cauliflower mosaic virus by restricting long-distance movement. Mol. Plant Microbe Interact. 20, 659-670. doi: 10.1094/MPMI-20-6-0659

Love, A. J., Yun, B. W., Laval, V., Loake, G. J., and Milner, J. J. (2005). Cauliflower mosaic virus, a compatible pathogen of Arabidopsis, engages three distinct defense-signaling pathways and activates rapid systemic generation of reactive oxygen species. Plant Physiol. 139, 935-948. doi: 10.1104/pp.105.066803

Macho, A. P., and Zipfel, C. (2014). Plant PRRs and the activation of innate immune signaling. Mol. Cell 54, 263-272. doi: 10.1016/j.molcel.2014.03.028

Mahajan, S. K., Chisholm, S. T., Whitham, S. A., and Carrington, J. C. (1998). Identification and characterization of a locus (RTM1) that restricts long-distance movement of tobacco etch virus in Arabidopsis thaliana. Plant J. 14, 177-186. doi: 10.1046/j.1365-313X.1998.00105.x

Malinowski, T., Cambra, M., Capote, N., Zawadzka, B., Gorris, M. T., Scorza, R., et al. (2006). Field Trials of plum clones transformed with the plum pox virus coat protein (PPV-CP) gene. Plant Dis. 90, 1012-1018. doi: 10.1094/PD-90-1012

Mandadi, K. K., and Scholthof, K.-B. G. (2013). Plant immune responses against viruses: how does a virus cause disease? Plant Cell 25, 1489-1505. doi: $10.1105 /$ tpc. 113.111658

Mandal, B., Mandal, S., Csinos, A. S., Martinez, N., Culbreath, A. K., and Pappu, H. R. (2008). Biological and molecular analyses of the acibenzolarS-methyl- induced systemic acquired resistance in flue-cured tobacco against tomato spotted wilt virus. Phytopathology 98, 196-204. doi: 10.1094/PHYTO-982-0196

Marathe, R., Anandalakshmi, R., Liu, Y., and Dinesh-Kumar, S. P. (2002). The tobacco mosaic virus resistance gene, N. Mol. Plant Pathol. 3, 167-172. doi: 10.1046/j.1364-3703.2002.00110.x

Mascher, M., and Stein, N. (2014). Genetic anchoring of whole-genome shotgun assemblies. Front. Genet. 5:208. doi: 10.3389/fgene.2014.00208

Maule, A. J., Caranta, C., and Boulton, M. I. (2007). Sources of natural resistance to plant viruses: status and prospects. Mol. Plant Pathol. 8, 223-231. doi: 10.1111/j.1364-3703.2007.00386.x

McCallum, C. M., Comai, L., Greene, E. A., and Henikoff, S. (2000). Targeting Induced Local Lesions IN Genomes (TILLING) for plant functional genomics. Plant Physiol. 123, 437-442. doi: 10.1104/pp.123.2.439

McKinney, H. H. (1926). Virus mixtures that may not be detected in young tobacco plants. Phytopathology 16, 883.

Medzhitov, R., and Janeway, C. A. (1997). Innate immunity: the virtues of a nonclonal system of recognition. Cell 91, 295-298. doi: 10.1016/S00928674(00)80412-2

Moffett, P. (2009). Mechanisms of recognition in dominant $\mathrm{R}$ gene mediated resistance. Adv. Virus Res. 75, 1-33. doi: 10.1016/S0065-3527(09)07501-0

Moissiard, G., and Voinnet, O. (2006). RNA silencing of host transcripts by cauliflower mosaic virus requires coordinated action of the four Arabidopsis Dicer-like proteins. Proc. Natl. Acad. Sci. U.S.A. 103, 19593-19598. doi: 10.1073/pnas.0604627103

Morel, J.-B., Godon, C., Mourrain, P., Béclin, C., Boutet, S., Feuerbach, F., et al. (2002). Fertile hypomorphic ARGONAUTE (agol) mutants impaired in posttranscriptional gene silencing and virus resistance. Plant Cell 14, 629-639. doi: $10.1105 /$ tpc.010358

Moreno, P., Ambrós, S., Albiach-Martí, M. R., Guerri, J., and Peña, L. (2008). Citrus tristeza virus: a pathogen that changed the course of the citrus industry. Mol. Plant Pathol. 9, 251-268. doi: 10.1111/j.1364-3703.2007.00455.x

Mundt, C. C. (2014). Durable resistance: a key to sustainable management of pathogens and pests. Infect. Genet. Evol. 27C, 446-455. doi: 10.1016/j.meegid.2014.01.011 
Nakahara, K. S., and Masuta, C. (2014). Interaction between viral RNA silencing suppressors and host factors in plant immunity. Curr. Opin. Plant Biol. 20, 88-95. doi: 10.1016/j.pbi.2014.05.004

Nakazono-Nagaoka, E., Takahashi, T., Shimizu, T., Kosaka, Y., Natsuaki, T., Omura, T., et al. (2009). Cross-protection against bean yellow mosaic virus (BYMV) and clover yellow vein virus by attenuated BYMV isolate M11. Phytopathology 99, 251-257. doi: 10.1094/PHYTO-99-3-0251

Nicaise, V., German-Retana, S., Sanjuán, R., Dubrana, M., Mazier, M., Maisonneuve, B., et al. (2003). The eukaryotic translation initiation factor $4 \mathrm{E}$ controls lettuce susceptibility to the potyvirus lettuce mosaic virus. Plant Physiol. 132, 1272-1282. doi: $10.1104 /$ pp.102.017855.1

Nicaise, V., Roux, M., and Zipfel, C. (2009). Recent advances in PAMP-triggered immunity against bacteria: pattern recognition receptors watch over and raise the alarm. Plant Physiol. 150, 1638-1647. doi: 10.1104/pp.109.139709

Nicholson, B. L., and White, K. A. (2014). Functional long-range RNA-RNA interactions in positive-strand RNA viruses. Nat. Rev. Microbiol. 12, 493-504. doi: 10.1038/nrmicro3288

Nieto, C., Piron, F., Dalmais, M., Marco, C. F., Moriones, E., Gómez-Guillamón, M. L., et al. (2007). EcoTILLING for the identification of allelic variants of melon eIF4E, a factor that controls virus susceptibility. BMC Plant Biol. 7:34. doi: 10.1186/1471-2229-7-34

Nishiguchi, M., and Kobayashi, K. (2011). Attenuated plant viruses: preventing virus diseases and understanding the molecular mechanism. J. Gen. Plant Pathol. 77, 221-229. doi: 10.1007/s10327-011-0318-x

Odipio, J., Ogwok, E., Taylor, N. J., Halsey, M., Bua, A., Fauquet, C. M., et al. (2013). RNAi-derived field resistance to cassava brown streak disease persists across the vegetative cropping cycle. GM Crops Food 5, 1-4.

Oka, K., Kobayashi, M., Mitsuhara, I., and Seo, S. (2013). Jasmonic acid negatively regulates resistance to tobacco mosaic virus in tobacco. Plant Cell Physiol. 54, 1999-2010. doi: 10.1093/pcp/pct137

Ordon, F., Habekuss, A., Kastirr, U., Rabenstein, F., and Kühne, T. (2009). Virus resistance in cereals: sources of resistance, genetics and breeding. J. Phytopathol 157, 535-545. doi: 10.1111/j.1439-0434.2009.01540.x

Otulak, K., and Garbaczewska, G. (2011). Cellular localisation of calcium ions during potato hypersensitive response to potato virus Y. Micron 42, 381-391. doi: 10.1016/j.micron.2010.11.001

Ouibrahim, L., Mazier, M., Estevan, J., Pagny, G., Decroocq, V., Desbiez, C., et al (2014). Cloning of the Arabidopsis rwml gene for resistance to watermelon mosaic virus points to a new function for natural virus resistance genes. Plant J. 79, 705-716. doi: 10.1111/tpj.12586

Padmanabhan, M. S., and Dinesh-Kumar, S. P. (2014). The conformational and subcellular compartmental dance of plant NLRs during viral recognition and defense signaling. Curr. Opin. Microbiol. 20, 55-61. doi: 10.1016/j.mib.2014.05.003

Pagny, G., Paulstephenraj, P. S., Poque, S., Sicard, O., Cosson, P., Eyquard, J.P., et al. (2012). Family-based linkage and association mapping reveals novel genes affecting plum pox virus infection in Arabidopsis thaliana. New Phytol. 196, 873-86. doi: 10.1111/j.1469-8137.2012.04289.x

Palloix, A., Ayme, V., and Moury, B. (2009). Durability of plant major resistance genes to pathogens depends on the genetic background, experimental evidence and consequences for breeding strategies. New Phytol. 183, 190-199. doi: 10.1111/j.1469-8137.2009.02827.x

Palloix, A., and Ordon, F. (2011). "Advanced breeding for virus resistance in plants," in Recent Advances in Plant Virology, eds C. Caranta, M. A. Aranda, M. Tepfer and J. J. Lopez-Moya (Norwich: Caister Academic Press), 195-218.

Park, S. W., Kaimoyo, E., Kumar, D., Mosher, S., and Klessig, D. F. (2007). Methyl salicylate is a critical mobile signal for plant systemic acquired resistance. Science 318, 113-116. doi: 10.1126/science.1147113

Patarroyo, C., Laliberté, J.-F., and Zheng, H. (2012). Hijack it, change it: how do plant viruses utilize the host secretory pathway for efficient viral replication and spread? Front. Plant Sci. 3:308. doi: 10.3389/fpls.2012.00308

Pestova, T. V, Kolupaeva, V. G., Lomakin, I. B., Pilipenko, E. V, Shatsky, I. N., Agol, V. I., et al. (2001). Molecular mechanisms of translation initiation in eukaryotes. Proc. Natl. Acad. Sci. U.S.A. 98, 7029-7036. doi: 10.1073/pnas.111145798

Piron, F., Nicolaï, M., Minoïa, S., Piednoir, E., Moretti, A., Salgues, A., et al. (2010). An induced mutation in tomato eiF4E leads to immunity to two potyviruses. PLoS ONE 5:e11313. doi: 10.1371/journal.pone.0011313

Pumplin, N., and Voinnet, O. (2013). RNA silencing suppression by plant pathogens: defence, counter-defence and counter-counter-defence. Nat. Rev. Microbiol. 11 , 745-760. doi: 10.1038/nrmicro3120
Qi, X., Bao, F. S., and Xie, Z. (2009). Small RNA deep sequencing reveals role for Arabidopsis thaliana RNA-dependent RNA polymerases in viral siRNA biogenesis. PLoS ONE 4:e4971. doi: 10.1371/journal.pone.0004971

Qu, F., Ye, X., and Morris, T. J. (2008). Arabidopsis DRB4, AGO1, AGO7, and RDR6 participate in a DCL4-initiated antiviral RNA silencing pathway negatively regulated by DCL1. Proc. Natl. Acad. Sci. U.S.A. 105, 14732-14737. doi: 10.1073/pnas.0805760105

Qu, J., Ye, J., and Fang, R. (2007). Artificial microRNA-mediated virus resistance in plants. J. Virol. 81, 6690-6699. doi: 10.1128/JVI.02457-06

Quenouille, J., Montarry, J., Palloix, A., and Moury, B. (2013). Farther, slower, stronger: how the plant genetic background protects a major resistance gene from breakdown. Mol. Plant Pathol. 14, 109-118. doi: 10.1111/j.13643703.2012.00834.x

Rairdan, G. J., Collier, S. M., Sacco, M. A., Baldwin, T. T., Boettrich, T., and Moffett, P. (2008). The coiled-coil and nucleotide binding domains of the potato Rx disease resistance protein function in pathogen recognition and signaling. Plant Cell 20, 739-751. doi: 10.1105/tpc.107.056036

Revers, F., Guiraud, T., Houvenaghel, M.-C., Mauduit, T., Le Gall, O., and Candresse, T. (2003). Multiple resistance phenotypes to lettuce mosaic virus among Arabidopsis thaliana accessions. Mol. Plant Microbe Interact. 16, 608-616. doi: 10.1094/MPMI.2003.16.7.608

Revers, F., and Nicaise, V. (2014). "Plant resistance to infection by viruses," in Encyclopedia of Life Sciences, ed. Wiley-Blackwell (Chichester: John Wiley \& Sons Ltd). doi: 10.1002/9780470015902.a0000757.pub3

Robert-Seilaniantz, A., Grant, M., and Jones, J. D. G. (2011). Hormone crosstalk in plant disease and defense: more than just JASMONATE-SALICYLATE antagonism. Annu. Rev. Phytopathol. 49, 317-343. doi: 10.1146/annurev-phyto-073009114447

Ronald, P. C., and Beutler, B. (2010). Plant and animal sensors of conserved microbial signatures. Science 330, 1061-1064. doi: 10.1126/science.1189468

Ross, F. A. (1961). Systemic acquired resistance induced by localized virus infections in plants. Virology 14, 340-358. doi: 10.1016/0042-6822(61)90319-1

Sandig, H., and Bulfone-Paus, S. (2012). TLR signaling in mast cells: common and unique features. Front. Immunol. 3:185. doi: 10.3389/fimmu.2012.00185

Sansregret, R., Dufour, V., Langlois, M., Daayf, F., Dunoyer, P., Voinnet, O., et al. (2013). Extreme resistance as a host counter-counter defense against viral suppression of RNA silencing. PLoS Pathog. 9:e1003435. doi: 10.1371/journal.ppat.1003435

Sasaya, T., Nakazono-Nagaoka, E., Saika, H., Aoki, H., Hiraguri, A., Netsu, O., et al. (2013). Transgenic strategies to confer resistance against viruses in rice plants. Front. Microbiol. 4:409. doi: 10.3389/fmicb.2013.00409

Sastry, S. K., and Zitter, T. A. (2014). "Management of virus and viroid diseases of crops in the tropics," in Plant Virus and Viroid Diseases in the Tropics, Vol. 2, Epidemiology and Management (Dordrecht: Springer), 149-480. doi: 10.1007/978-94-007-7820-7_2

Sasvari, Z., Izotova, L., Kinzy, T. G., and Nagy, P. D. (2011). Synergistic roles of eukaryotic translation elongation factors $1 \mathrm{~B} \gamma$ and $1 \mathrm{~A}$ in stimulation of tombusvirus minus-strand synthesis. PLoS Pathog. 7:e1002438. doi: 10.1371/journal.ppat.1002438

Schröder, M., and Bowie, A. G. (2007). An arms race: innate antiviral responses and counteracting viral strategies. Biochem. Soc. Trans. 35, 1512-1514. doi: 10.1042/BST0351512

Schwessinger, B., and Ronald, P. C. (2012). Plant innate immunity: perception of conserved microbial signatures. Annu. Rev. Plant Biol. 63, 451-482. doi: 10.1146/annurev-arplant-042811-105518

Seo, J.-K., Kwon, S.-J., Cho, W. K., Choi, H.-S., and Kim, K.-H. (2014). Type 2C protein phosphatase is a key regulator of antiviral extreme resistance limiting virus spread. Sci. Rep. 4, 5905. doi: 10.1038/srep05905

Seo, Y.-S., Rojas, M. R., Lee, J.-Y., Lee, S.-W., Jeon, J.-S., Ronald, P., et al. (2006). A viral resistance gene from common bean functions across plant families and is up-regulated in a non-virus-specific manner. Proc. Natl. Acad. Sci. U.S.A. 103, 11856-11861. doi: 10.1073/pnas.0604815103

Serrano, C., González-Cruz, J., Jauregui, F., Medina, C., Mancilla, P., Matus, J. T., et al. (2008). Genetic and histological studies on the delayed systemic movement of tobacco mosaic virus in Arabidopsis thaliana. BMC Genet. 9:59. doi: 10.1186/1471-2156-9-59

Shabala, S., Babourina, O., Rengel, Z., and Nemchinov, L. G. (2010). Noninvasive microelectrode potassium flux measurements as a potential tool for 
early recognition of virus-host compatibility in plants. Planta 232, 807-815. doi: 10.1007/s00425-010-1213-y

Shabala, S., Baekgaard, L., Shabala, L., Fuglsang, A., Babourina, O., Palmgren, M. G., et al. (2011). Plasma membrane $\mathrm{Ca}^{2+}$ transporters mediate virus-induced acquired resistance to oxidative stress. Plant. Cell Environ. 34, 406-417. doi: 10.1111/j.1365-3040.2010.02251.x

Shekhawat, U. K. S., Ganapathi, T. R., and Hadapad, A. B. (2012). Transgenic banana plants expressing small interfering RNAs targeted against viral replication initiation gene display high-level resistance to banana bunchy top virus infection. J. Gen. Virol. 93, 1804-1813. doi: 10.1099/vir.0.041871-0

Shi, A., Chen, P., Li, D., Zheng, C., Hou, A., and Zhang, B. (2009). Gene pyramiding of genes of soybean mosaic virus resistance. Mol. Breed. 23, 113-124. doi: 10.1007/s11032-008-9219-x

Shimizu, T., Nakazono-Nagaoka, E., Akita, F., Uehara-Ichiki, T., Omura, T., and Sasaya, T. (2011). Immunity to rice black streaked dwarf virus, a plant reovirus can be achieved in rice plants by RNA silencing against the gene for the viroplasm component protein. Virus Res. 160, 400-403. doi: 10.1016/j.virusres.2011. 05.011

Shivaprasad, P. V., Rajeswaran, R., Blevins, T., Schoelz, J., Meins, F., Hohn, T., et al (2008). The CaMV transactivator/viroplasmin interferes with RDR6-dependent trans-acting and secondary siRNA pathways in Arabidopsis. Nucleic Acids Res. 36, 5896-5909. doi: 10.1093/nar/gkn590

Slootweg, E., Roosien, J., Spiridon, L. N., Petrescu, A.-J., Tameling, W., Joosten, M., et al. (2010). Nucleocytoplasmic distribution is required for activation of resistance by the potato NB-LRR receptor $\mathrm{Rx} 1$ and is balanced by its functional domains. Plant Cell 22, 4195-4215. doi: 10.1105/tpc.110.077537

Soosaar, J. L. M., Burch-Smith, T. M., and Dinesh-Kumar, S. P. (2005). Mechanisms of plant resistance to viruses. Nat. Rev. Microbiol. 3, 789-798. doi 10.1038/nrmicro1239

Spoel, S. H., and Dong, X. (2012). How do plants achieve immunity? Defence without specialized immune cells. Nat. Rev. Immunol. 12, 89-100. doi: $10.1038 /$ nri3141

Takeshita, M., Okuda, M., Okuda, S., Hyodo, A., Hamano, K., Furuya, N., et al. (2013). Induction of antiviral responses by acibenzolar-s-methyl against cucurbit chlorotic yellows virus in Melon. Phytopathology 103, 960-965. doi: 10.1094/PHYTO-08-12-0188-R

Taki, A., Yamagishi, N., and Yoshikawa, N. (2013). Development of apple latent spherical virus-based vaccines against three tospoviruses. Virus Res. 176, 251-258. doi: 10.1016/j.virusres.2013.06.015

Taliansky, M. E., Brown, J. W. S., Rajamäki, M. L., Valkonen, J. P. T., and Kalinina, N. O. (2010). Involvement of the plant nucleolus in virus and viroid infections. Parallels with animal pathosystems. Adv. Virus Res. 77, 119-158. doi: 10.1016/B978-0-12-385034-8.00005-3

Tameling, W. I. L., Nooijen, C., Ludwig, N., Boter, M., Slootweg, E., Goverse, A., et al. (2010). RanGAP2 mediates nucleocytoplasmic partitioning of the NB-LRR immune receptor $\mathrm{Rx}$ in the Solanaceae, thereby dictating $\mathrm{Rx}$ function. Plant Cell 22, 4176-4194. doi: 10.1105/tpc.110.077461

Tamura, A., Kato, T., Taki, A., Sone, M., Satoh, N., Yamagishi, N., et al. (2013). Preventive and curative effects of Apple latent spherical virus vectors harboring part of the target virus genome against potyvirus and cucumovirus infections. Virology 446, 314-324. doi: 10.1016/j.virol.2013.08.019

Tenllado, F., Llave, C., and Díaz-Ruíz, J. R. (2004). RNA interference as a new biotechnological tool for the control of virus diseases in plants. Virus Res. 102 , 85-96. doi: 10.1016/j.virusres.2004.01.019

Thaler, J. S., Humphrey, P. T., and Whiteman, N. K. (2012). Evolution of jasmonate and salicylate signal crosstalk. Trends Plant Sci. 17, 260-270. doi: 10.1016/j.tplants.2012.02.010

Thivierge, K., Nicaise, V., Dufresne, P. J., Cotton, S., Laliberté, J.-F., Le Gall, O., et al. (2005). Plant virus RNAs. Coordinated recruitment of conserved host functions by $(+)$ ssRNA viruses during early infection events. Plant Physiol. 138, 1822-1827. doi: 10.1104/pp.105.064105.1822

Thresh, J. M., and Cooter, R. J. (2005). Strategies for controlling cassava mosaic virus disease in Africa. Plant Pathol. 54, 587-614. doi: 10.1111/j.13653059.2005.01282.x

Trejo-Saavedra, D. L., García-Neria, M. A., and Rivera-Bustamante, R. F. (2013). Benzothiadiazole (BTH) induces resistance to pepper golden mosaic virus (PepGMV) in pepper (Capsicum annuum L.). Biol. Res. 46, 333-340. doi: 10.4067/S0716-97602013000400004
Tricoli, D. M., Carney, K. J., Russell, P. F., McMaster, J. R., and Groff, D. W. (1995). Field-evaluation of transgenic squash containing single or multiple virus coat protein gene constructs for resistance to cucumber mosaic-virus. Artif. Cells Blood Substit. Immobil. Biotechnol. 13, 1458-1465. doi: 10.1038/nbt1295-1458

Truniger, V., and Aranda, M. A. (2009). Recessive resistance to plant viruses. $A d v$. Virus Res. 119-159. doi: 10.1016/S0065-3527(09)07504-6

Tsuda, K., Sato, M., Glazebrook, J., Cohen, J. D., and Katagiri, F. (2008). Interplay between MAMP-triggered and SA-mediated defense responses. Plant J. 53, 763775. doi: 10.1111/j.1365-313X.2007.03369.x

Ueda, H., Yamaguchi, Y., and Sano, H. (2006). Direct interaction between the tobacco mosaic virus helicase domain and the ATP-bound resistance protein, $\mathrm{N}$ factor during the hypersensitive response in tobacco plants. Plant Mol. Biol. 61, 31-45. doi: 10.1007/s11103-005-5817-8

Vaistij, F. E., and Jones, L. (2009). Compromised virus-induced gene silencing in RDR6-deficient plants. Plant Physiol. 149, 1399-1407. doi: 10.1104/pp. 108.132688

Valkonen, J. P. T., Rajamäki, M.-L., and Kekarainen, T. (2002). Mapping of viral genomic regions important in cross-protection between strains of a potyvirus. Mol. Plant Microbe Interact. 15, 683-692. doi: 10.1094/MPMI.2002.15. 7.683

Verlaan, M. G., Hutton, S. F., Ibrahem, R. M., Kormelink, R., Visser, R. G. F., Scott, J. W., et al. (2013). The tomato yellow leaf curl virus resistance genes Ty-1 and Ty-3 are allelic and code for DFDGD-Class RNA-dependent RNA polymerases. PLoS Genet. 9:e1003399. doi: 10.1371/journal.pgen.1003399

Vlot, A. C., Klessig, D. F., and Park, S. W. (2008). Systemic acquired resistance: the elusive signal(s). Curr. Opin. Plant Biol. 11, 436-442. doi: 10.1016/j.pbi. 2008.05.003

Vogler, H., Akbergenov, R., Shivaprasad, P. V, Dang, V., Fasler, M., Kwon, M.O., etal. (2007). Modification of small RNAs associated with suppression of RNA silencing by tobamovirus replicase protein. J. Virol. 81, 10379-10388. doi: 10.1128/JVI.00727-07

Voinnet, O. (2001). RNA silencing as a plant immune system against viruses. Trends Genet. 17, 449-459. doi: 10.1016/S0168-9525(01)02367-8

Voinnet, O. (2005). Induction and suppression of RNA silencing: insights from viral infections. Nat. Rev. Genet. 6, 206-220. doi: 10.1038/nrg1555

Wagner, S., Stuttmann, J., Rietz, S., Guerois, R., Brunstein, E., Bautor, J., et al. (2013). Structural basis for signaling by exclusive EDS1 heteromeric complexes with SAG101 or PAD4 in plant innate immunity. Cell Host Microbe 14, 619-630. doi: 10.1016/j.chom.2013.11.006

Wale, S., Platt, B., and Cattlin, N. D. (2008). Diseases, Pests and Disorders of Potatoes: A Colour Handbook. London: Manson Publishing Ltd.

Wang, A., and Krishnaswamy, S. (2012). Eukaryotic translation initiation factor 4Emediated recessive resistance to plant viruses and its utility in crop improvement. Mol. Plant Pathol. 13, 795-803. doi: 10.1111/j.1364-3703.2012.00791.x

Wang, H. L. (1991). Effectiveness of cross protection by a mild strain of zucchini yellow mosaic virus in cucumber, melon, and squash. Plant Dis. 75, 203. doi: 10.1094/PD-75-0203

Wang, X.-B., Jovel, J., Udomporn, P., Wang, Y., Wu, Q., Li, W.-X., et al. (2011). The 21-nucleotide, but not 22-nucleotide, viral secondary small interfering RNAs direct potent antiviral defense by two cooperative argonautes in Arabidopsis thaliana. Plant Cell 23, 1625-1638. doi: 10.1105/tpc.110.082305

Waterhouse, P. M., Wang, M. B., and Lough, T. (2001). Gene silencing as an adaptive defence against viruses. Nature 411, 834-842. doi: 10.1038/35081168

Wen, F., Lister, R. M., and Fattouh, F. A. (1991). Cross-protection among strains of barley yellow dwarf virus. J. Gen. Virol. 72, 791-799. doi: 10.1099/0022-1317-724-791

Werner, K., Friedt, W., and Ordon, F. (2005). Strategies for pyramiding resistance genes against the barley yellow mosaic virus complex (BaMMV, BaYMV, BaYMV2). Mol. Breed. 16, 45-55. doi: 10.1007/s11032-005-3445-2

Whitham, S., McCormick, S., and Baker, B. (1996). The N gene of tobacco confers resistance to tobacco mosaic virus in transgenic tomato. Proc. Natl. Acad. Sci. U.S.A. 93, 8776-8781. doi: 10.1073/pnas.93.16.8776

Yadav, J. S., Ogwok, E., Wagaba, H., Patil, B. L., Bagewadi, B., Alicai, T., et al. (2011). RNAi-mediated resistance to cassava brown streak uganda virus in transgenic cassava. Mol. Plant Pathol. 12, 677-687. doi: 10.1111/j.1364-3703.2010. 00700.x

Yan, N., and Chen, Z. J. (2012). Intrinsic antiviral immunity. Nat. Immunol. 13, 214-222. doi: 10.1038/ni.2229 
Yang, H., Gou, X., He, K., Xi, D., Du, J., Lin, H., et al. (2010). BAK1 and BKK1 in Arabidopsis thaliana confer reduced susceptibility to turnip crinkle virus. Eur. J. Plant Pathol. 127, 149-156. doi: 10.1007/s10658-010-9581-5

Yang, P., Lüpken, T., Habekuss, A., Hensel, G., Steuernagel, B., Kilian, B., et al. (2014). PROTEIN DISULFIDE ISOMERASE LIKE 5-1 is a susceptibility factor to plant viruses. Proc. Natl. Acad. Sci. U.S.A. 111, 2104-2109. doi: 10.1073/pnas.1320362111

Yi, S. Y., Shirasu, K., Moon, J. S., Lee, S. G., and Kwon, S. Y. (2014). The activated SA and JA signaling pathways have an influence on flg22-triggered oxidative burst and callose deposition. PLoS ONE 9:e88951. doi: 10.1371/journal.pone. 0088951

Yokota, S.-I., Okabayashi, T., and Fujii, N. (2010). The battle between virus and host: modulation of Toll-like receptor signaling pathways by virus infection. Mediators Inflamm. 2010, 184328. doi: 10.1155/2010/184328

Yoon, J. Y., Ahn, H. II, Kim, M., Tsuda, S., and Ryu, K. H. (2006). Pepper mild mottle virus pathogenicity determinants and cross protection effect of attenuated mutants in pepper. Virus Res. 118, 23-30. doi: 10.1016/j.virusres.2005.11.004

You, B.-J., Chiang, C.-H., Chen, L.-F., Su, W.-C., and Yeh, S.-D. (2005). Engineered mild strains of papaya ringspot virus for broader cross protection in cucurbits. Phytopathology 95, 533-540. doi: 10.1094/PHYTO-95-0533

Zagrai, I., Capote, N., Ravelonandro, M., Cambra, M., Zagrai, L., and Scorza, R. (2008). Plum pox virus silencing of C5 transgenic plums is stable under challenge inoculation with heterologous viruses. J. Plant Pathol. 90, S1-S63.

Zavaliev, R., Levy, A., Gera, A., and Epel, B. L. (2013). Subcellular dynamics and role of Arabidopsis $\beta$-1,3-glucanases in cell-to-cell movement of tobamoviruses. Mol. Plant Microbe Interact. 26, 1016-1030. doi: 10.1094/MPMI-03-130062-R

Zhang, G., Chen, M., Li, L., Xu, Z., Chen, X., Guo, J., et al. (2009). Overexpression of the soybean GmERF3 gene, an AP2/ERF type transcription factor for increased tolerances to salt, drought, and diseases in transgenic tobacco. J. Exp. Bot. 60, 3781-3796. doi: 10.1093/jxb/erp214

Zhang, X., Li, H., Zhang, J., Zhang, C., Gong, P., Ziaf, K., et al. (2011a). Expression of artificial microRNAs in tomato confers efficient and stable virus resistance in a cell-autonomous manner. Transgenic Res. 20, 569-581. doi: 10.1007/s11248-0109440-3

Zhang, X., Sato, S., Ye, X., Dorrance, A. E., Morris, T. J., Clemente, T. E., etal. (2011b). Robust RNAi-based resistance to mixed infection of three viruses in soybean plants expressing separate short hairpins from a single transgene. Phytopathology 101, 1264-1269. doi: 10.1094/PHYTO-0211-0056
Zhang, X., Singh, J., Li, D., and Qu, F. (2012). Temperature-dependent survival of turnip crinkle virus-infected Arabidopsis plants relies on an RNA silencing-based defense that requires DCL2, AGO2, and HEN1. J. Virol. 86, 6847-6854. doi: 10.1128/JVI.00497-12

Zhao, D., and Song, G. Q. (2014). Rootstock-to-scion transfer of transgene-derived small interfering RNAs and their effect on virus resistance in nontransgenic sweet cherry. Plant Biotechnol. J. doi: 10.1111/pbi.12243 [Epub ahead of print].

Zhu, F., Xi, D.-H., Yuan, S., Xu, F., Zhang, D.-W., and Lin, H.-H. (2014). Salicylic acid and jasmonic acid are essential for systemic resistance against tobacco mosaic virus in Nicotiana benthamiana. Mol. Plant Microbe Interact. 27, 567-577. doi: 10.1094/MPMI-11-13-0349-R

Zhu, S., Jeong, R. D., Venugopal, S. C., Lapchyk, L., Navarre, D., Kachroo, A., et al. (2011). Sag101 forms a ternary complex with EDS1 and PAD4 and is required for resistance signaling against turnip crinkle virus. PLoS Pathog. 7:e1002318. doi: 10.1371/journal.ppat.1002318

Ziebell, H., and Carr, J. P. (2010). Cross-protection: a century of mystery. Adv. Virus Res. 76, 211-264. doi: 10.1016/S0065-3527(10)76006-1

Ziebell, H., Payne, T., Berry, J. O., Walsh, J. A., and Carr, J. P. (2007). A cucumber mosaic virus mutant lacking the $2 \mathrm{~b}$ counter-defence protein gene provides protection against wild-type strains. J. Gen. Virol. 88, 2862-2871. doi: 10.1099/vir.0.83138-0

Zipfel, C., and Felix, G. (2005). Plants and animals: a different taste for microbes? Curr. Opin. Plant Biol. 8, 353-360. doi: 10.1016/j.pbi.2005.05.004

Conflict of Interest Statement: The author declares that the research was conducted in the absence of any commercial or financial relationships that could be construed as a potential conflict of interest.

Received: 15 September 2014; accepted: 04 November 2014; published online: 21 November 2014.

Citation: Nicaise V (2014) Crop immunity against viruses: outcomes and future challenges. Front. Plant Sci. 5:660. doi: 10.3389/fpls.2014.00660

This article was submitted to Plant-Microbe Interaction, a section of the journal Frontiers in Plant Science.

Copyright (C) 2014 Nicaise. This is an open-access article distributed under the terms of the Creative Commons Attribution License (CC BY). The use, distribution or reproduction in other forums is permitted, provided the original author(s) or licensor are credited and that the original publication in this journal is cited, in accordance with accepted academic practice. No use, distribution or reproduction is permitted which does not comply with these terms. 